\title{
1 Geochronology and zircon Hf isotope geochemistry of \\ 2 granites in the giant Chalukou Mo deposit, NE China: \\ 3 Implications for tectonic setting
}

4

5

Cheng Zhang ${ }^{\mathrm{a}, \mathrm{b}}$, Nuo Li ${ }^{\text {c, d, e* }}$

6

${ }^{a}$ Zijin Mining Group Co. Ltd, Shanghang, 364200 Fujian, China

$7 \quad{ }^{b}$ Key Laboratory of Orogen and Crust Evolution, Peking University, Beijing 100871, China

$8{ }^{c}$ Xinjiang Research Center for Mineral Resources, Xinjiang Institute of Ecology and

9 Geography, Chinese Academy of Sciences, Urumqi 830011, China

10

${ }^{d}$ Xinjiang Key Laboratory of Mineral Resources and Digital Geology, Urumqi 830011,

11 China

$12{ }^{e}$ Department of Earth Sciences, Aarhus University, Høegh-Guldbergs Gade 2, DK-8000

13 Aarhus C, Denmark

14 * Corresponding author, email: nuolipku@126.com; linuo9102110@163.com

15

16 
17

18

19

\section{Abstract}

In this contribution, the largest porphyry Mo deposit in NE China, Chalukou, is selected to provide insights into the tectonic evolution of NE China. The deposit was considered to be rift-related (or Climax-type) porphyry Mo deposit developed in an extensional setting, while other researchers attributed its formation to the subduction of the Paleo-Pacific Ocean. In view of different granite petrogenesis between rift-type and subduction-type porphyry Mo deposits, geochronological and zircon Lu-Hf isotope studies have been carried out on granitic rocks associated with the Chalukou deposit. Zircon grains from the ore-host monzogranite and ore-causative granite porphyry yield weighted mean ${ }^{206} \mathrm{~Pb} /{ }^{238} \mathrm{U}$ ages of $166 \pm 2$ Ma and $152 \pm 2$ Ma, with molybdenite samples yielding a Re-Os isochron age of $150 \pm 2$ Ma, indicating a Jurassic age for both granitic intrusion and Mo mineralization. Zircon $\varepsilon H f(t)$ values of monzogranite and granite porphyry range from 0.9 to 3.0 and from -1.4 to 0.5 , respectively. When integrated with published zircon $\mathrm{Lu}-\mathrm{Hf}$ isotopic data, our data suggest that the barren granites (both pre- and post-ore) were mainly derived from mantle-derived juvenile rocks, whereas the syn-ore granite requires additional involvement of old continental crust. Thus, a contribution of continental crust to Mo mineralization is suggested. The petrogenesis and geochemical data reveal that the Chalukou deposit is a subduction-related porphyry Mo deposits and not rift-related. Integrated evidence links its formation to the southeastward subduction of the Mongol-Okhotsk Ocean, instead of the westward subduction of the Paleo-Pacific Ocean. 
Zircon U-Pb age; Hf isotope; molybdenite Re-Os age; porphyry Mo deposit; Chalukou; the Great Hingan Range

\section{Introduction}

Mineral systems are the products of a complex combination of tectono-thermal processes that result in anomalous metals concentration. They are not randomly distributed in time and/or in space, but form in through a series of events involving various combinations of tectono-magmatic, metamorphism, and hydrothermal processes (Chen et al., 2008; Pirajno and Zhou, 2015). Since the advent of the plate tectonic theory, economic geologists attempted to understand the relationships between mineral systems and geodynamic settings. For instance, Sillitoe (1972) outlined a plate tectonic model to account for the genesis and distribution of porphyry Cu deposits. Meyer (1981), Mitchell and Garson (1981) and Sawkins (1984, 1990) convincingly demonstrated how deposits of diamonds formed in anorogenic continental hot spots, deposits of salt and limestone-hosted $\mathrm{Pb}-\mathrm{Zn}$ formed on passive margin, sandstone-hosted $\mathrm{U}$ and $\mathrm{Cu}$ developed within intracontinental basins. Subsequently, considerable progress was made in connecting the formation of ore deposits to global tectonics, and several classification schemes for ore deposits based on tectonic setting have been proposed (e.g. Kerrich et al., 2000; Meyer, 1988; Pirajno, 2009, 2016). For instance, porphyry Mo deposits can be classified into three types, rift-related (e.g. Climax, high-fluorine type), subduction-related (e. g Endako, low-fluorine type) and collision-related 
(Dabie type) (Chen et al., 2016a; Li et al., 2012a, 2013; Mi et al., 2015; Wang et al., 2016b; Yang et al., 2015a, 2016).

The Chalukou porphyry Mo deposit, located in the northern Great Hingan Range (Fig. 1), is the largest Mo deposit in NE China, with a proven reserve of 2.46 Mt Mo metal at an average grade of $0.11 \%$, plus $0.37 \mathrm{Mt} \mathrm{Pb}$ and $\mathrm{Zn}$ at an average grade of 1.27\% (Li et al., 2014; Nie et al., 2011). This deposit was once considered to be a porphyry Mo deposit linked to continental rifting (Li et al., 2014; Nie et al., 2013), which, in turn, constrains its formation to an extensional tectonic regime. Other researchers, however, argued that its formation resulted from the subduction of the Paleo-Pacific oceanic plate (Liu et al., 2014; Xiong et al., 2015). Considering the fact that the ore-causative granitoids responsible for either rifting or subduction-related porphyry Mo deposits have different geochemical signatures and magmatic sources (Ludington and Plumlee, 2009; Taylor et al., 2012), detailed geochronological and isotopic studies (including molybdenite Re-Os dating, zircon $\mathrm{U}-\mathrm{Pb}$ dating and Lu-Hf analysis) were employed to constrain the emplacement/mineralization ages and granite petrogenesis. Our results show that, the Jurassic granitoids in the Chalukou deposit originated from partial melting of juvenile crust. Therefore, this deposit shares similar geological and geochemical features with porphyry Mo deposits developed in continental arc settings. When taking into consideration the spatio-temporal distribution and geochemical features of porphyry Mo deposits in NE China, it is proposed that the Chalukou deposit was formed in a continental arc setting, caused by the southeastward subduction of the Mongol-Okhotsk Ocean. 
80

81

82

83

84

\section{Geological setting}

As the eastern segment of the CAOB, the Great Hingan Range (GHR) is bounded by the Mongol-Okhotsk Suture to the north, the Kangbao-Chifeng Fault to the south, the Nenjiang Fault to the east (Fig. 1B). The giant Chalukou Mo deposit is located in the northern part of the GHR, which includes two tectonic units named Erguna Massif and Hingan Massif (Fig. 1B; Chen et al., 2012; Qi et al., 2005). The Erguna Massif is considered as the eastern extension of the Central Mongolian microcontinent (Wu et al., 2011). It is mainly composed of voluminous Paleozoic and Mesozoic granitoids, and Mesozoic volcanic rocks. The basement discontinuously occurs in restricted areas and is composed of Precambrian metamorphic supracrustal rocks and associated granitic complexes (Fig. 1C). The metamorphic rocks included upper greenschist- to lower amphibolite-facies rocks, such as amphibolites, gneisses, schists, leptynites, leucoleptynites, and marbles. These are conventionally subdivided into the Xinghuadukou, Luomahu and Jiageda groups (HBGMR, 1993). They were previously regarded as Archean or Paleoproterozoic in age (Biao et al., 1999; HBGMR, 1993), but recent zircon U-Pb dating revealed Neoproterozoic ages (Ge et al., 2015; Miao et al., 2007; Wu et al., 2012). Traditionally, granitoids in the Erguna Massif were assigned to the Paleozoic in the eastern part and the Proterozoic-Paleozoic in the western part (HBGMR, 1993). Recently obtained geochronological data indicate multiple episodes of granitic magmatism, with the majority formed in the Cretaceous (118-132 Ma), Jurassic to Triassic (182-220 Ma) and Devonian to Cambrian (416-517 Ma), and less in the Triassic to Carboniferous (244-336 Ma) and Neoproterozoic (792-927 Ma) (Wu et al., 2011). Mesozoic volcanism is widespread and is subdivided into the Tamulangou, Jixiangfeng, 
102

Shangkuli and Yiliekede formations from old to young (HBGMR, 1993). Detailed geochronological data indicate a Jurassic-Cretaceous depositional age (Wang et al., 2006; Xu et al., 2013).

The Hingan Massif is characterized by voluminous Mesozoic granites and volcanic rocks (Fig. 1C; Zhang et al., 2010; Zhou and Wilde, 2013). Precambrian basement units may be present locally, but no reliable evidence is available. The metamorphic rocks that were assumed to be Proterozoic in age (HBGMR, 1993; IMBGMR, 1991) are actually Paleozoic and/or Mesozoic in age as constrained by more recent zircon U-Pb dating (Miao et al., 2007; Sun et al., 2014; Xu et al., 2013). The Paleozoic strata (mainly marine volcano-clastic rocks) are well developed, especially in the middle and eastern part, and locally outcrop as roof pendants in granite. Contemporaneous granitoids were metamorphosed and deformed (Han et al., 2011). Late Mesozoic granitoids, however, are undeformed and widespread throughout the region (Wu et al., 2003; Zhou and Wilde, 2013). The Mesozoic to Cenozoic sedimentary and volcanic rocks are volumetrically important, accounting for about $70 \%$ of all exposed rocks (Fig. 1C).

\section{Local and ore geology}

The Chalukou porphyry Mo deposit is located $64 \mathrm{~km}$ northwest of Xiaoyangqi Town,

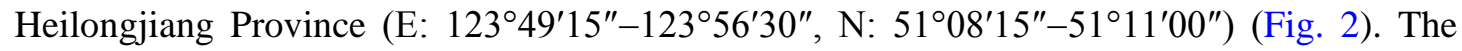
mineralized area is $8 \mathrm{~km}$ long and $5 \mathrm{~km}$ wide, and is divided into east and west sections by the Duobukuer River (Fig. 2). Compared to the western section, the eastern one is explored and studied in more detail. 
123

124

125

126

127

128

129

130

131

132

133

134

135

136

137

138

139

140

\subsection{Lithologies and structures}

Rocks in the Chalukou area include the Dawangzi Formation and Baiyingaolao Formation (Fig. 3A). The Dawangzi Formation is a suite of low-grade meta-volcanic and meta-sedimentary rocks that are composed of quartz-chlorite schists, quartz-biotite schists and minor marble. This formation locally occurs to the southeast and northwest part of the deposit and was traditionally considered to be Neoproterozoic-Early Cambrian in age (HBGMR, 1993). Zircon U-Pb data, however, constraint its formation to the Silurian-Cambrian (Miao et al., 2007; Sun et al., 2014). The Jurassic Baiyingaolao Formation is widely distributed, and is mainly composed of rhyolites, dacites, andesites and intermediate-felsic tuffs ( $\mathrm{Lv}$ et al., 2010). These rocks are one of the main ore-host and as such are hydrothermally altered (see below).

NE- and NW-trending faults and volcanic ring fractures are dominant in the deposit area (Fig. 2). They were formed prior to or simultaneously with Mo mineralization, and controlled the distribution of both intrusions and orebodies. The thick, high-grade and continuous orebodies are preferentially located at the intersections between NE- and NW-trending faults. Explosive breccias pipes, lenses and veins are also well developed in the mineralized zone (Fig. 3A and 4C).

\subsection{Intrusive rocks}

Multiple episodes of igneous activity are recognized in the mining area. The Late Paleozoic quartz diorite in the southwestern corner intruded into Silurian-Cambrian metamorphic rocks, and was crosscut by later intrusions (Fig. 3A). The Jurassic monzogranite, 
144

which underlies the western part of the deposit is one of the main host rock to Mo mineralization in the Chalukou area. It intruded into the Late Paleozoic quartz diorite and is overlain by Jurassic volcanic-sedimentary rocks (Fig. 3A, B). The Late Jurassic granitoids record a complex history that includes emplacement, solidification, locally intense veining, dyke intrusion, hydrothermal alteration and Mo mineralization. They display a range of compositions from granite porphyry, quartz porphyry, aplite porphyry and granite. Some post-ore intrusions and extrusions, such as diorite porphyry, quartz monzonite porphyry, rhyolite porphyry or diorite porphyry, intruded or covered early granitoids and Mo orebodies (Fig. 2 and 3).

\subsection{Mineralization}

Both Mo and $\mathrm{Pb}-\mathrm{Zn}$ mineralization can be identified in the Chalukou deposit. Mo mineralization mainly occurs as quartz-sulfide veinlets in the central part, whereas the $\mathrm{Pb}-\mathrm{Zn}$ mineralization is hosted by NW-dipping veins with dip angles of $30-50^{\circ}$ in distal zones (Liu et al., 2014a).

The Mo orebodies are generally hosted by the monzogranite, granite porphyry, breccia pipes and Jurassic volcanic-sedimentary rocks (Fig. 3B). The largest Mo orebody is 1,800 m long, 200-1,000 m wide and 815 m thick (Nie et al., 2011). A vertical variation can be recognized (Liu et al., 2011; Nie et al., 2011): (1) at the top, the Mo orebodies occur as thin layers and veins in the felsic volcanic rocks, and are characterized by low grade (with an average of $0.06 \%$ ), small scale (several to dozens of meters thick) and are discontinuous; (2) in the middle part, the Mo orebodies are very thick and lenticular, mainly hosted by felsic 
165

166

167

168

169

170

171

172

173

174

175

176

177

178

179

180

181

182

183

184

volcanic rocks and granite porphyry, and characterized by high grade ( $0.06 \%$ to $0.26 \%)$, large scale (with thickness of over $100 \mathrm{~m}$ ) and good continuity; (3) at the base, the Mo orebodies are located in granite porphyry and breccia pipes, with thickness of nearly $100 \mathrm{~m}$ and Mo grades of $0.08 \%$ to $0.53 \%$.

Molybdenite can occur: (a) as blades or films filling fractures of granite porphyry, monzogranite, Jurassic volcanic-sedimentary rocks and pre-Mesozoic metamorphic rocks (Fig. 4F); (b) as disseminations in quartz-dominated veinlets (Fig. 4G); or (c) as matrix in breccias that cements clasts of granite porphyry and Jurassic volcanic-sedimentary rocks (Fig. 4H). Other ore minerals include pyrite, sphalerite and galena, with minor chalcopyrite, pyrrhotite and magnetite. Gangue minerals are mainly K-feldspar, quartz, plagioclase, sericite, calcite, chlorite and fluorite.

\subsection{Hydrothermal alteration}

Four alteration zones can be recognized from the center of the porphyry stock outwards, i.e. potassic, phyllic, argillic and propylitic, though their boundaries are transitional and therefore not sharply defined. Mo mineralization is associated with potassic and phyllic alteration (Fig. 4K-O), while $\mathrm{Pb}-\mathrm{Zn}$ mineralization is closely associated with propylitic alteration (Liu et al., 2011; Nie et al., 2011, 2013).

The potassic alteration occurs mainly in the granite porphyry and the wall rocks (Fig. 3A). It is characterized by an assemblage of K-feldspar + quartz \pm biotite with rare sericite and anhydrite. Hydrothermal quartz and K-feldspar usually replace magmatic quartz and feldspar within the intrusion, or occur as veins and veinlets (Fig. 4I). The phyllic alteration 
186

187

zone is represented by the mineral assemblage of quartz + sericite + hydromuscovite + pyrite \pm kaolinite \pm calcite (Fig. 4J), and mainly is developed in the Jurassic volcanic-sedimentary rocks, monzogranite and some granite porphyry (Fig. 3A). Abundant sericite and/or hydromuscovite either occur as veins or replacement of magmatic minerals, such as plagioclase, K-feldspar and biotite in the intrusion. The argillic alteration zone is observed mainly in the Jurassic volcanic-sedimentary rocks (Fig. 3A), with a characteristic assemblage of quartz + kaolinite + chlorite + calcite \pm fluorite \pm pyrite (Fig. $4 \mathrm{~L}$ ). Propylitic alteration is manifested as extensive replacement of feldspar, biotite and muscovite by epidote, chlorite and calcite (Fig. 4M), and is well developed in the monzogranite, the Jurassic volcanic-sedimentary rocks and Silurian-Cambrian metamorphic rocks (Fig. 3A). Propylitic alteration overprints early alteration types at all scales.

\section{Sampling and methodology}

\subsection{Sampling}

Seven molybdenite samples for Re-Os analyses were collected from different depth of drill core ZKHD903 in the eastern section (Fig. 3A). They include both molybdenite-only (CLK-03, 04, 05, 06, 07) and quartz-molybdenite veins (CLK-10, 11) (Fig. 4F, N, O).

Two samples were selected for zircon $\mathrm{U}-\mathrm{Pb}$ dating and Lu-Hf analysis (Fig. 3A). Sample CLKY-01 is a reddish medium to coarse-grained monzogranite collected from 1225 m depth of drill core GK-02. It is composed of 35 to 40 vol.\% plagioclase, 30 to 35 vol.\% K-feldspar, 25 to 30 vol.\% quartz and 2 to 5 vol.\% biotite (Fig. 4A, D). Plagioclase with polysynthetic twins is subhedral or euhedral and partially altered to sericite (Fig. 4D). 
K-feldspar is subhedral or anhedral and commonly replaced by kaolinite. Quartz is mostly subhedral or anhedral, showing myrmekitic texture and undulating extinction. Biotite is partially altered to chlorite, generating fine-grained opaque minerals. The major accessory minerals are zircon, sphene and magnetite.

Sample CLKY-07 is granite porphyry collected from 1018 m depth of drill core ZKHD903. It is strongly altered, with minor sulfide mineralization (Fig. 4B). It is reddish, massive and porphyritic. Phenocrysts with sizes of $0.5-5 \mathrm{~mm}$ account for about 10 vol.\% of the whole rock and consist mainly of quartz ( 3 vol.\%), K-feldspar ( 4 vol.\%), plagioclase ( 3 vol.\%), and lesser amount of biotite (<1 vol.\%) (Fig. 4E). Plagioclase phenocrysts are subhedral-euhedral with obvious sericite alteration. K-feldspar phenocrysts are subhedral-anhedral and altered to kaolinite. Sometimes the anhedral quartz phenocrysts are partly eroded with embayed boundaries. The matrix is composed of quartz, K-feldspar, plagioclase and mafic minerals, with accessory apatite, zircon, sphene and magnetite (Fig. 4 E).

\subsection{Re-Os analyses}

Molybdenite separates were obtained by crushing the ore samples to 100 mesh in a porcelain mill, gravity sorting, electromagnetic separation, and finally handpicked to a purity of more than 98\% under a binocular microscope. Re-Os isotopes were performed and analyzed by a TJA X-series ICP-MS at the Re-Os Laboratory, National Research Center of

Geoanalysis, Chinese Academy of Geological Sciences (CAGS). The uncertainty in each individual age determination is about $1.5 \%$, including the uncertainty of the decay constant of 
${ }^{187} \mathrm{Re}$, uncertainty of the isotope ratio measurement, and the spike calibration. The details of the chemical procedure have been described by Du et al. (2004), Markey et al. (1998) and Stein et al. (1998).

\subsection{Zircon $\mathrm{U}-\mathrm{Pb}$ dating and $\mathrm{Lu}-\mathrm{H} f$ isotope analyses}

Zircon separates were mounted in epoxy resin together with several reference crystals, including 91500 and GJ-1. Then the mount was polished and coated with gold. Cathodoluminescence (CL) images were obtained using a CAMECA SX50 microprobe at the Institute of Geology and Geophysics, Chinese Academy of Sciences, in order to identify internal textures and choose potential analysis sites. These zircons were first analyzed for their $\mathrm{U}-\mathrm{Pb}$ isotopic composition, followed by Hf isotope analysis on the same domains, in order to get coupled $\mathrm{U}-\mathrm{Pb}-\mathrm{Hf}$ isotope data.

$\mathrm{U}-\mathrm{Pb}$ dating of zircons was conducted by LA-ICP-MS at the State Key Laboratory of Geological Processes and Mineral Resources, China University of Geosciences, Wuhan. Detailed operating conditions for the laser ablation system and the ICP-MS instrument and data reduction are the same as description by Liu et al. (2010). Laser sampling was performed using a GeoLas 2005. An Agilent 7500a ICP-MS instrument was used to acquire ion-signal intensities. Helium was applied as a carrier gas. Argon was used as the make-up gas and mixed with the carrier gas via a T-connector before entering the ICP. Nitrogen was added into the central gas flow $(\mathrm{Ar}+\mathrm{He})$ of the Ar plasma to decrease the detection limit and improve precision (Hu et al., 2012). Each analysis incorporated a background acquisition of approximately 20-30 s (gas blank) followed by $50 \mathrm{~s}$ data acquisition from the sample. The 
Agilent Chemstation was utilized for the acquisition of each individual analysis. Off-line selection and integration of background and analyses signals, and time-drift correction and quantitative calibration for U-Pb dating were performed by ICPMSDataCal (Liu et al., 2010). Zircon 91500 was used as external standard for $\mathrm{U}-\mathrm{Pb}$ dating, and was analyzed twice every 5 analyses. Time-dependent drift of $\mathrm{U}-\mathrm{Th}-\mathrm{Pb}$ isotopic ratios was corrected using a linear interpolation (with time) for every five analyses according to the variations of 91500 (Liu et al., 2010). Preferred U-Th-Pb isotopic ratios used for 91500 are from Wiedenbeck et al. (1995). Uncertainty of preferred values for the external standard 91500 was propagated to the final results of the samples. Common $\mathrm{Pb}$ was corrected according to the method proposed by Anderson (2002). Concordia diagrams and weighted mean calculations were made using Isoplot/Ex_ver3 (Ludwig, 2003).

Lu-Hf isotope analysis was conducted using a Neptune Plus MC-ICP-MS (Thermo Fisher Scientific, Germany) in combination with a GeoLas 2005 excimer ArF laser ablation system (Lambda Physik, Göttingen, Germany) that was hosted at the state Key Laboratory of Geological Processes and Mineral Resources, China University of Geosciences in Wuhan. The energy density of laser ablation that was used in this study was $5.3 \mathrm{~J} \cdot \mathrm{cm}^{-2}$. Helium was used as the carrier gas within the ablation cell and was merged with argon (makeup gas) after the ablation cell. All data were acquired on zircon in single spot ablation mode at a spot size of $44 \mu \mathrm{m}$. Each measurement consisted of $20 \mathrm{~s}$ of acquisition of the background signal followed by $50 \mathrm{~s}$ of ablation signal acquisition. Detailed operating conditions for the laser ablation system and the MC-ICP-MS instrument and analytical method are the same as described by Hu et al. (2012). The major limitation to accurate in situ zircon Hf isotope 
271 determination by LA-MC-ICP-MS is the very large isobaric interference from ${ }^{176} \mathrm{Yb}$ and, to a 272 lesser extent ${ }^{176} \mathrm{Lu}$ on ${ }^{176} \mathrm{Hf}$. We applied the directly obtained $\beta_{\mathrm{Yb}}$ value from the zircon 273 sample itself in real-time in this study. The ${ }^{179} \mathrm{Hf} /{ }^{177} \mathrm{Hf}$ and ${ }^{173} \mathrm{Yb} /{ }^{171} \mathrm{Yb}$ ratios were used to 274 calculate the mass bias of $\mathrm{Hf}\left(\beta_{\mathrm{Hf}}\right)$ and $\mathrm{Yb}\left(\beta_{\mathrm{Yb}}\right)$, which were normalised to ${ }^{179} \mathrm{Hf} /{ }^{177} \mathrm{Hf}=$ 2750.7325 and ${ }^{173} \mathrm{Yb} /{ }^{171} \mathrm{Yb}=1.13017$ (Segal et al., 2003) using an exponential correction for 276 mass bias. The interference of ${ }^{176} \mathrm{Yb}$ on ${ }^{176} \mathrm{Hf}$ was corrected by measuring the 277 interference-free ${ }^{173} \mathrm{Yb}$ isotope and using ${ }^{176} \mathrm{Yb} /{ }^{173} \mathrm{Yb}=0.79381$ (Segal et al., 2003) to 278 calculate ${ }^{176} \mathrm{Yb} /{ }^{177} \mathrm{Hf}$. Similarly, the relatively minor interference of ${ }^{176} \mathrm{Lu}$ on ${ }^{176} \mathrm{Hf}$ was 279 corrected by measuring the intensity of the interference-free ${ }^{175} \mathrm{Lu}$ isotope and using the 280 recommended value of ${ }^{176} \mathrm{Lu} /{ }^{175} \mathrm{Lu}=0.02656$ (Blichert-Toft and Albarede, 1997) to calculate $281{ }^{176} \mathrm{Lu} /{ }^{177} \mathrm{Hf}$. We used the mass bias of $\mathrm{Yb}\left(\beta_{\mathrm{Yb}}\right)$ to calculate the mass fractionation of $\mathrm{Lu}$ 282 because of their similar physicochemical properties. Off-line selection and integration of 283 analyte signals, and mass bias calibrations were performed using ICPMSDataCal (Liu et al., 284 2010). Zircon GJ-1 was used as the reference standard, with a weighted mean ${ }^{176} \mathrm{Hf} /{ }^{177} \mathrm{Hf}$ ratio 285 of $0.282010 \pm 15(1 \sigma)$ during our routine analyses, which is in good agreement with the 286 recommended ratios $0.282015 \pm 19(2 \sigma)$ for GJ-1 (Elhlou et al., 2006). Analytical ratios of ${ }^{176} \mathrm{Yb} /{ }^{177} \mathrm{Hf},{ }^{176} \mathrm{Lu} /{ }^{177} \mathrm{Hf}$ and ${ }^{176} \mathrm{Hf} /{ }^{177} \mathrm{Hf}$ are reported with $2 \sigma$ error. 288 Initial ${ }^{176} \mathrm{Hf} /{ }^{177} \mathrm{Hf}$ ratio, i.e. $\operatorname{\varepsilon Hf}(\mathrm{t})$, is calculated referring to chondrite at the time of zircon 289 growth from magma. The decay constant of $1.867 \times 10^{-11}$ year ${ }^{-1}$ for ${ }^{176} \mathrm{Lu}$ (Söderlund et al., 290 2004) and the chondritic ratios of ${ }^{176} \mathrm{Hf} /{ }^{177} \mathrm{Hf}(0.282772)$ and ${ }^{176} \mathrm{Lu} /{ }^{177} \mathrm{Hf}(0.0332)$ introduced 291 by Blichert-Toft and Albarede (1997) were adopted in calculations. Single-stage Hf model 292 ages $\left(\mathrm{T}_{\mathrm{DM} 1}\right)$ are calculated relative to the depleted mantle with a present day ${ }^{176} \mathrm{Hf} /{ }^{177} \mathrm{Hf}$ ratios 
293

294

295

296

297

298

299

300

301

302

303

304

305

306

307

308

309

310

311

of 0.28325 and ${ }^{176} \mathrm{Lu} /{ }^{177} \mathrm{Hf}$ of 0.0384 (Griffin et al., 2000). Two-stage Hf model ages $\left(\mathrm{T}_{\mathrm{DM} 2}\right)$ are calculated by referring to the $\mathrm{f}_{\mathrm{Lu} / \mathrm{Hf}}$ value of -0.55 for the average continental crust (Griffin et al., 2002). The $\mathrm{f}_{\mathrm{Lu} / \mathrm{Hf}}$ ratio equals to $\left({ }^{176} \mathrm{Lu} /{ }^{177} \mathrm{Hf}\right)_{\mathrm{s}} /\left({ }^{176} \mathrm{Lu} /{ }^{177} \mathrm{Hf}\right)_{\mathrm{CHUR}}-1$, where the $\left({ }^{176} \mathrm{Lu} /{ }^{177} \mathrm{Hf}\right)_{\mathrm{CHUR}}=0.0332$, and the $\left({ }^{176} \mathrm{Lu} /{ }^{177} \mathrm{Hf}\right)_{\mathrm{s}}$ value is obtained from sample analysis.

\section{Analytical results}

\subsection{Re-Os geochronology}

The Re-Os isotope data of seven molybdenite samples are listed in Table 1 with $2 \sigma$ errors. The samples have a relatively wide range of Re and ${ }^{187}$ Os contents (i.e. $3.14-19.49$ ppm and 4.74-30.55 ppb, respectively), but the positive correlation between Re and Os is clear. The Re-Os model ages are consistent, ranging from 146 Ma to 150 Ma with a weighted mean age of $148 \pm 1$ Ma (Table 1). Using Isoplot/Ex_ver3 (Ludwig, 2003), the data yield an isochron age of $(150 \pm 2)$ Ma with MSWD $=1.9$ and an initial ${ }^{187}$ Os of $-0.42 \pm 0.28 \mathrm{ppb}$ (Fig. 5).

\subsection{Zircon morphology and $\mathrm{U}-\mathrm{Pb}$ dating}

Zircon grains collected from sample CLKY-01 are euhedral and have sharp facets and pointed tips. They are mainly colorless and transparent, with lengths ranging from 100 to 200 $\mu \mathrm{m}$ and length/width ratios from 2:1 to 4:1. Oscillatory zoning is well developed (Fig. 6).

Obtained $\mathrm{Th} / \mathrm{U}$ values range from 0.45 to 1.09 (Table 1 ), indicating a typically magmatic genesis (Wu and Zheng, 2004). All of the eighteen analyses are concordant, and the ${ }^{206} \mathrm{~Pb} /{ }^{238} \mathrm{U}$ 
ages scatter between $161 \pm 2$ and $171 \pm 2$ Ma (Table 1), averaging at $166.2 \pm 1.5$ Ma (95\% confidence level, MSWD = 1.8, $\mathrm{n}=18$; Fig. 7).

Zircon crystals collected from sample CLKY-07 are colorless and transparent, showing sub- to euhedral prismatic shapes with sharp facets and pointed tips (Fig. 6). They range in size from 80 to $150 \mu \mathrm{m}$ in length with length/width ratios of about 1.5:1-3:1. Some zircons are cracked, have inclusions and/or have been partially dissolved in the host magmas (CLKY-07-01, 02, 13; Fig. 6). The CL images reveal a variety of internal textures ranging from irregular patchy to fine-scale oscillatory zoning. LA-ICP-MS analyses were performed on sixteen spots (Fig. 6, Table 2). Their Th/U ratios are relatively high (0.52-1.02; Table 2), consistent with the features of magmatic zircons (Wu and Zheng, 2004). The data yield ${ }^{206} \mathrm{~Pb} /{ }^{238} \mathrm{U}$ ages of $149-157 \mathrm{Ma}$ (Table 2), with a weighted mean age of $152 \pm 2 \mathrm{Ma}(95 \%$ confidence level, MSWD = 1.3, n = 16; Fig. 7).

\subsection{Zircon Hf isotopes}

The results of zircon Lu-Hf isotopic analyses are listed in Table 3 and shown in Fig. 8. Hf isotopic data, expressed as values of epsilon $\mathrm{Hf}$ at the time of formation $(\varepsilon \mathrm{Hf}(\mathrm{t}))$, from the ore-host monzogranite porphyry and ore-causative granite porphyry as well as other phases making up the Chalukou granitoids are plotted versus time in Fig. 8.

The ${ }^{176} \mathrm{Lu} /{ }^{177} \mathrm{Hf}$ ratios are very low (0.000575-0.001652 for sample CLKY-01 and 0.000817-0.001587 for sample CLKY-07, respectively), indicating very little radiogenic Hf. Thus, the measured ${ }^{176} \mathrm{Hf} /{ }^{177} \mathrm{Hf}$ ratios can approximately represent initial Hf isotopic composition. 
The obtained ${ }^{176} \mathrm{Hf} /{ }^{177} \mathrm{Hf}$ ratios of eighteen spots from sample CLKY-01 have limited variation, ranging from $0.282701 \pm 0.000007$ to $0.282761 \pm 0.000012$ with a weighted average of $0.282721 \pm 0.000009(1 \sigma, \mathrm{n}=18)$. Calculated $\varepsilon \mathrm{Hf}(\mathrm{t})$ values vary from 0.9 to 3.0, with an average of $1.7 \pm 0.6(1 \sigma, \mathrm{n}=18)$. Corresponding two-stage $\mathrm{Hf}$ model ages $\left(\mathrm{T}_{\mathrm{DM} 2}\right)$ range from 1016 to $1232 \mathrm{Ma}$, with a weighted mean of $1116 \mathrm{Ma}$ (Table 3).

Sixteen zircons from Sample CLKY-07 display variable ${ }^{176} \mathrm{Hf} /{ }^{177} \mathrm{Hf}$ ratios of $0.282644 \pm$ 0.000006 to $0.282689 \pm 0.000017$ with a weighted average of $0.282667 \pm 0.000012(1 \sigma, \mathrm{n}=$ 16) (Table 3). Obtained $\varepsilon \mathrm{Hf}(\mathrm{t})$ values are -1.4 to 0.5 , with an average of $-0.4 \pm 0.7(1 \sigma, \mathrm{n}=$ 16). Two-stage Hf model ages ( $\mathrm{T}_{\mathrm{DM} 2}$ ) range from 1174 to $1284 \mathrm{Ma}$, with a weighted mean of 1228 Ma (Table 3).

\section{Discussion}

\subsection{Timing of magmatism and mineralization}

Available data show that the duration of magmatic activity responsible for hydrothermal mineralization varies significantly, from less than one million years to more than tens of million years (see Li et al., 2013 and references therein). The Chalukou deposit is a typical porphyry Mo deposit characterized by large tonnage, but low-grade stockwork and breccia-hosted ores, as well as large-scale hydrothermal alteration and spatial and a genetic association with granite porphyry. A combination of zircon $\mathrm{U}-\mathrm{Pb}$ and molybdenite $\mathrm{Re}-\mathrm{Os}$ ages obtained by Li et al. (2014), Liu et al. (2014a), Nie et al. (2011) and from this study 
353

activity and deposit formation. We suggest a long-lived magmatic system with a short-lived mineralization event for the Chalukou deposit as follows (Fig. 9).

The monzogranite from the neighboring district of the Chalukou deposit is the oldest Mesozoic intrusion. It is barren and poorly altered, with a zircon U-Pb age of $172.4 \pm 1.6 \mathrm{Ma}$ (Li et al., 2014). Following its intrusion, another phase of monzogranite was emplaced in the northwest and southeast part of the ore district. New U-Pb zircon ages (Li et al., 2014; Liu et al., 2014a; this paper) suggested that its emplacement took place between 166 and $162 \mathrm{Ma}$. This phase, however, is still ore-barren but serves as important host rock to Mo mineralization. Afterward, several porphyritic phases, including aplite porphyry, granite porphyry and quartz porphyry, intruded at ca. $148 \mathrm{Ma}$ ( $\mathrm{Li}$ et al., 2014; Liu et al., 2014a; this paper). These porphyry intrusions are considered as the main contributor that resulted in extensive and intensive Mo mineralization. New molybdenite Re-Os isochron method places a robust mineralization age of $150 \pm 2$ Ma, verifying their co-occurrence. Subsequently, post-ore intrusive (such as diorite porphyry and quartz monzonite porphyry) and extrusive (such as andesite porphyry and rhyolite porphyry) rocks were emplaced and destroyed or covered the Mo orebodies. These rocks yield crystallization ages ranging from $142 \mathrm{Ma}$ to $128 \mathrm{Ma}$ (Li et al., 2014; Liu et al., 2014a). Hence, it is concluded that the magmatic event at the Chalukou deposit span ca. 45 Ma (from 172 to $128 \mathrm{Ma}$ ). Related Mo mineralization, however, is short-lived, as constrained to 150-147 Ma by molybdenite Re-Os dating (Liu et al., 2014a; Nie et al., 2011; this paper). 


\subsection{Contribution of continental crust to the ore-causative granitoids}

Zircon can effectively record the primary Lu-Hf isotopic characteristics, due to its low concentration of initial Lu and consequently negligible radiogenic Hf within it (Amelin et al., 2000; Griffin et al., 2002). Since Hf is partitioned more strongly into melts than Lu during partial melting, the crust generally has lower ${ }^{176} \mathrm{Lu} /{ }^{177} \mathrm{Hf}$ and ${ }^{176} \mathrm{Hf} /{ }^{177} \mathrm{Hf}$ ratios than the mantle. Accordingly, granitoids with positive $\varepsilon \mathrm{Hf}(\mathrm{t})$ values are considered to be sourced from the partial melting of juvenile crustal materials, while the negative $\varepsilon \mathrm{Hf}(\mathrm{t})$ values indicate a source of old crust (Sui et al., 2007; Sun et al., 2005). As shown in Fig. 8 and Table 3, the monzogranite and granite porphyry of the Chalukou Mo deposit display different zircon Hf isotopic compositions, indicating discrepant sources of magma. The positive $\varepsilon \mathrm{Hf}(\mathrm{t})$ values of the monzogranite (0.9-3.0) indicate a predominantly juvenile protolith. However, the granite porphyry has much lower $\varepsilon \mathrm{Hf}(\mathrm{t})$ values (-1.4-0.5) than those of monzogranite, although they have similar two-stage Hf model ages (1174-1284 Ma and 1016-1232 Ma).

When integrated with published zircon Lu-Hf isotopic data (Li et al., 2014; Liu et al., 2014), our data allow us to address the question of whether there are fundamental differences in magma sources of barren versus mineralized granite. From Fig. 8 we can see that both the pre- and post-ore, barren granites are characterized by limited and positive $\varepsilon H f(t)$ values, indicating their juvenile character and suggesting their derivation from source rock or magmas separated shortly from the upper mantle. By contrast, the syn-ore rocks, including granite porphyry, quartz porphyry, granite and apalite porphyry, are characterized by more heterogeneous $\varepsilon \mathrm{Hf}(\mathrm{t})$ values (-4.2 to 10.2$)$ than the barren rocks. Their positive $\varepsilon \mathrm{Hf}(\mathrm{t})$ values are comparable with those of barren rocks, although zircon grains with negative $\varepsilon \mathrm{Hf}(\mathrm{t})$ values 
also exist, reflecting the contamination of older, evolved continental crust in the magma generation processes. Thus it is concluded that the contribution of old continental crust is critical to Mo mineralization (Chen et al., 2012, 2016b; Zhang and Li, 2014). Actually, this conclusion is verified by the prominent spatial relationship between porphyry Mo deposits and continental crust: the majority of porphyry Mo deposits are underlain by continental crust in tectonic settings such as continental arc, back-arc rift or continental orogeny, whereas in island arc where no continental crustal sources are inferred, porphyry Mo deposits are limited (Misra, 2000; Sillitoe, 1980, 2010).

\subsection{Granitoid petrogenesis as a constraint to the genetic type of the deposit}

Three subtypes of porphyry Mo deposits are distinguished in the context of their intricate processes of ore formation, namely rift-related, subduction-related and collision-related (Table 4). The Chalukou deposit was at first assigned to rifting processes by Nie et al. (2013) based on evidences such as: the A-type affinity of the main ore-causative rocks, the inverted-cup-shape of the ore-body, the hydrothermal alteration, as well as the $\mathrm{P}-\mathrm{T}$ condition of the ore-forming fluids. However, the argillic alteration, which is widespread in the Chalukou deposit is actually not well-developed in rift-related Mo deposits. The shape of the orebody and the $\mathrm{P}-\mathrm{T}$ condition of ore-forming fluids cannot be regarded as reliable criteria for assessing the tectonic regime under which the deposit may have formed (Chen et al., 2016a; Li et al., 2012a, 2013; Ludington and Plumlee, 2009; Taylor et al., 2012).

Another important evidence disputing the rift- affinity of the Chalukou deposit lies on the petrogenesis of granitoids. Typical rift-related porphyry Mo deposits are invariably 
associated with A-type granites. The classic view interpreted the dominant parental melt to be derived from evolved lower continental crust instead of juvenile crust. Such arguments are based mainly on the per-aluminous character of the most evolved magmas, the variably negative $\varepsilon \mathrm{Nd}(\mathrm{t})$, moderately radiogenic $\mathrm{Sr}$ and non-radiogenic $\mathrm{Pb}$ isotope ratios (Farmer and Depaolo, 1984; Pettke et al., 2010; Stein, 1985; Zartman, 1974). For instance, 3 samples from Henderson yield $\varepsilon N d(t)$ values ranging from -9.5 to -9.9 that are indistinguishable from the high end $\varepsilon N d$ of Precambrian (1.6 to $1.8 \mathrm{Ga}$ ) basement rocks (Farmer and Depaolo, 1984). Hence, the granitic magmas were considered to be derived mainly from mid-Proterozoic crust. The Pine Grove topaz rhyolite that is associated with a Climax-type porphyry Mo deposit displays $\left({ }^{87} \mathrm{Sr} /{ }^{86} \mathrm{Sr}\right)_{\mathrm{i}}$ values between 0.706 and 0.710 , and $\varepsilon \mathrm{Nd}(\mathrm{t})$ values between -11 and -9 (Christiansen et al., 2007). All these data emphasize significant contribution of old, highly evolved lower crust (Ludington and Plumlee, 2009; Seedorff et al., 2005).

Biotite is the dominant mafic mineral in the Chalukou ore-causative granitoids, and no mafic alkaline silicates, such as arfvedsonite or riebeckite are observed. Geochemical analysis reveals low proportions of $\mathrm{Zr}, \mathrm{Nb}, \mathrm{Y}$, La, Ce and $\mathrm{Ga}$, suggesting I-type affinity instead of A-type (Li et al., 2014; Liu et al., 2015). Moreover, the large variation in zircon $\varepsilon \mathrm{Hf}(\mathrm{t})$ values from -4.2 to 10.2 indicate variable proportions of older continental crust and juvenile sources. Such a scenario contrasts with a rift- related porphyry Mo deposit, instead it is suggestive of a subduction system in which the production of granite was initiated by extensive basaltic underplating, accompanied by partial melting of a range of lithologic associations. Further, the trace element concentrations in the ore-causative granite are also comparable with subduction-related deposits: with Rb ranging from 141 to 229 ppm (mainly <200 ppm), Sr 
from 24 to 387 ppm (mainly <100 ppm), Nb from 9 to 46 ppm (mainly <15 ppm), and Zr from 89 to 285 ppm (mainly >100 ppm) (Table 4). Hence, the petrogenesis of the Chalukou granitoids supports a subduction link. This conclusion is also evidenced by the widespread argillic alteration and the low, if any, contents of $\mathrm{CO}_{2}$ in the ore-forming fluids (Liu et al., 2014b; Xiong et al., 2015).

\subsection{Implications for the geodynamic setting of the Chalukou porphyry Mo deposit}

With the Chalukou deposit considered as subduction-related, the question can be posed: which ocean was responsible for the formation of the continental arc? The Paleo-Asian Ocean can be excluded as it had closed in Late Permian-Triassic times (Chen et al., 2007; Zhang and Li, 2014). Hence, only the Paleo-Pacific Ocean or the Mongol-Okhotsk Ocean can be considered to have developed subduction zones or plates, which were ultimately responsible for partial melting and the emplacement of granitic rocks and porphyritic granites, which caused the formation of the Chalukou deposit.

Taking into consideration that: (1) spatially, the Chalukou deposit is located in the northeastern part of the Hingan Massif, which is too far away from the East Asian continental margin to be accounted for the effect of the subduction of the Paleo-Pacific plate (Chen et al., 2007; Li et al., 2007; Qi et al., 2005); (2) temporally, the subduction of the Paleo-Pacific plate beneath the Eurasia continent began in the Early Cretaceous (Chen et al., 2016b; Engebretson et al., 1985; Shao and Tang, 2015; Shao et al., 2013), which is much later than the formation of the Chalukou deposit at ca. $150 \mathrm{Ma}$; (3) porphyry Mo deposits and related magmatic rocks aged 160-130 Ma have been only reported to the west of the Songliao basin, whereas are 
absent to its eastern part (Chen et al., 2012, 2016b), thereby subduction of the Paleo-Pacific plate is not related to the emplacement of granitoids and the Mo mineralization at Chalukou.

On the other hand, abundant evidences indicate that granite emplacement and mineralization at the Chalukou deposit is related to the subduction of the Mongol-Okhotsk Ocean. Extensive studies of the Early Mesozoic granitoids along the Mongol-Okhotsk Suture have revealed that these rocks are dominated by granodiorite, monzogranite, syenogranite, biotite granite, and diorite, and are widely distributed along both sides of the suture (Tang et al., 2014; Wu et al., 2011). Petrologically, the genetic types of granite also show variations, where Jurassic granites are mainly I-type, whereas A-type granites were only emplaced in the Early Cretaceous. Thus, the Jurassic granites formed in an active continental margin related to the bidirectional subduction of the Mongol-Okhotsk Ocean (Tang et al., 2014; Wu et al., 2011; Xu et al., 2013).

Another line of evidence supporting the southeastward subduction of the Mongol-Okhotsk oceanic plate comes from Jurassic porphyry deposits located in the western part of NE China (Fig. 1C). They include, $\mathrm{Fe}-\mathrm{Cu}, \mathrm{Cu}-\mathrm{Mo}$ and $\mathrm{Mo}-(\mathrm{Cu}-\mathrm{Pb}-\mathrm{Zn})$ mineral systems, which are commonly observed in continental arc settings. Moreover, the corresponding ore-forming fluids are of high temperature, of high salinity, with little, if any, $\mathrm{CO}_{2}$ (Li et al., 2012b; Liu et al., 2014b; Wang et al., 2009). These features are commonly observed in porphyry systems formed in subduction-related continental arcs (Chen and $\mathrm{Li}$, 2009). Furthermore, a spatial and temporal distribution can be recognized (Fig. 1C). Spatially, the $\mathrm{Cu}-(\mathrm{Fe}-\mathrm{Mo})$ deposits are distributed in the northwestern parts of the GHR (mainly in the Erguna Massif), whereas $\mathrm{Mo}-(\mathrm{Cu}-\mathrm{Pb}-\mathrm{Zn})$ deposits occur in the inner parts of GHR (both in 
481

482

483

484

485

486

487

the Erguna Massif and the Xing'an Massif). Temporally, $\mathrm{Cu}-(\mathrm{Fe}-\mathrm{Mo})$ deposits formed earlier (e.g. the 178 Ma Wunugetushan Cu-Mo deposit, Chen et al., 2011; Li et al., 2007, 2012b; the 176 Ma Sankuanggou Fe-Cu deposit, Chu et al., 2012), whereas Mo-(Cu-Pb-Zn) deposits formed later (from 150 Ma to 129 Ma, Liu et al., 2014a; Nie et al., 2011; Wang et al., 2009, 2016a; Zhai et al., 2009; Zhang et al., 2013 and this paper). Such a spatio-temporal variation is commonly observed in a continental subduction setting and reinforces a southeastward subduction of the Mongol-Okhotsk Ocean.

Additional evidence comes from paleomagnetic studies, which indicated that the Mongol-Okhotsk Ocean was still open in the early Late Jurassic (Cogne et al., 2005; Enkin et al., 1992; Kravchinsky et al., 2002; Metelkin et al., 2007; Zhao et al., 1996). Yang et al. (2015b) reviewed systematically the Late Jurassic-Early Cretaceous stratigraphic and structural evolution of basins in northern China and Mongolia, and concluded that during Late Jurassic, an oceanic arm several hundred kilometers wide existed between eastern Amuria (including the Great Hingan Range) and Siberia.

Based on the above discussion, it is clear that the Chalukou deposit is a porphyry Mo deposit developed in a continental arc setting, and can be interpreted as a product of the southeastward subduction of the Mongol-Okhotsk Ocean and not of the westward subduction of the Paleo-Pacific Ocean (Fig. 10). Such a conclusion can also be supported by porphyry molybdenum deposits from the southern segment of the Great Hingan Range (Chen et al., 2012, 2016b; Wang et al., 2016a). 
501

502

503

504

505

506

507

508

509

510

511

512

513

514

515

516

517

518

519

520

521

\section{Concluding remarks}

(1) The Chalukou deposit is a typical porphyry Mo deposit associated with a multistage porphyry complex, with a zircon $\mathrm{U}-\mathrm{Pb}$ age of $166 \pm 2$ Ma for the ore-hosting monzogranite and $152 \pm 2$ Ma for the ore-causative granite porphyry. Mo mineralization occurred at $150 \pm 2$ Ma (molybdenite Re-Os isochron age).

(2) The monzogranite and granite porphyry yield zircon $\varepsilon \mathrm{Hf}(\mathrm{t})$ values of $0.9-3.0$ and $-1.4-0.5$, respectively. Combined with previous geochemical data, it is suggested that the barren magmas (both pre-ore and post-ore) were originated mainly from partial melting of juvenile crust, whereas the ore-causative granites require additional involvement of old continental crust.

(3) The Chalukou deposit shares similar geological and geochemical features with subduction-related porphyry Mo deposits. Its formation indicates the southeastward subduction of the Mongol-Okhotsk Ocean lasted to at least Late Jurassic in the eastern part.

\section{Acknowledgements}

This is a contribution from the Working Group on Mineral Deposits in Collisional

Orogens (IAGOD), and has been financially granted by the National Basic Research Program (No. 2012CB416600), the National Science Foundation of China (No. 41390443) and the CSC-sponsored Scholarship Program for Visiting Scholars (including Postdoctoral) (No. 201504910471). The field work was supported by Chifeng Yuanye Changshun Geological Exploration Co., Ltd. and Heilongjiang Institute of Geological Survey. We are grateful for Prof. Zhaochu $\mathrm{Hu}$ and Drs. Chao Li, Yongfei Yang, Jun Zhong and Richen Zhong for 
assistance with the analytical work. Constructive suggestions from Franco Pirajno, Thomas Ulrich and Yanjing Chen, and anonymous reviewers greatly improved the quality of the paper.

\section{References}

Amelin, Y., Lee, D.C., Halliday, A.N., 2000. Early-Middle Archean crustal evolution deduced from $\mathrm{Lu}-\mathrm{Hf}$ and $\mathrm{U}-\mathrm{Pb}$ isotopic studies of single zircon grains. Geochemic et Cosmochimica Acta 64, 4205-4225.

Anderson, T., 2002. Correction of common lead in U-Pb analyses that do not report ${ }^{204} \mathrm{~Pb}$. Chem. Geol. 192, 59-79.

Biao, S.H., Li, Y.C., She, X.H., Zhou, X.F., Ma, L.L., 1999. The geochemical characteristics of the Xinghuadukou Group in the Lulin forestry center, Tahe, Heilongjiang province. Region. Geol. Chi. 18, 28-32 (in Chinese with English abstract).

Blichert-Toft, J., Albarede, F., 1997. The Lu-Hf isotope geochemistry of chondrites and the evolution of the mantle-crust system. Earth Planet. Sci. Lett. 148, 243-258.

Chen, Y.J., Li, N., 2009. Nature of ore-fluids of intracontinental intrusion-related hypothermal deposits and its difference from those in island arcs. Acta Petrol. Sin. 25, 2477-2508 (in Chinese with English abstract).

Chen, Y.J., Chen, H.Y., Zaw, K., Pirajno, F., Zhang, Z.J., 2004. The geodynamic setting of large-scale metallogenesis in mainland China, exemplified by skarn type gold deposits. Earth Sci. Front. 11, 57-83. 
Chen, Y.J., Chen, H.Y., Zaw, K., Pirajno, F., Zhang, Z.J., 2007. Geodynamic settings and tectonic model of skarn gold deposits in China: an overview. Ore Geol. Rev. 31, 139-169.

Chen, Y.J., Xiao, W.J., Zhang, J.J., 2008. Ore-system as a geodynamic probe. Geol. in China 35, 1059-1073 (in Chinese with English abstract).

Chen, Z.G., Zhang, L.C., Wan, B., Wu, H.Y., Cleven, N., 2011. Geochronology and geochemistry of the Wunugetushan porphyry $\mathrm{Cu}-\mathrm{Mo}$ deposit in NE China, and their geological significance. Ore Geol. Rev. 43, 92-105.

Chen, Y.J., Zhang, C., Li, N., Yang, Y.F., Deng, K., 2012. Geology of the Mo deposits in Northeast China. J. Jilin Univ. (Earth Sci. Ed.) 42, 1223-1268 (in Chinese with English abstract).

Chen, Y.J., Wang, P., Li, N., Yang, Y.F., Pirajno, F., 2016a. The collision-type porphyry Mo deposits in Dabie Shan, China. Ore Geol. Rev. doi: 10.1016/j.oregeorev.2016.03.025.

Chen, Y.J., Zhang, C., Wang, P., Pirajno, F., Li, N., 2016b. The Mo deposits of Northeast China: a powerful indicator of tectonic settings and associated evolutionary trends. Ore Geol. Rev. this special issue.

Christiansen, E.H., Haapala, I., Hart, G.L., 2007. Are Cenozoic topaz rhyolites the erupted equivalents of Proterozoic rapakivi granites? Examples from the western United States and Finland. Lithos 97, 219-246.

Chu, S.X., Liu, J.M., Xu, J.H., Wei, H., Tong, K.Y., 2012. Zircon U-Pb dating, petrogenesis and tectonic significance of the granodiorite in the Sankuanggou skarn $\mathrm{Fe}-\mathrm{Cu}$ deposit, Heilongjiang Province. Acta Petrol. Sin. 28, 433-450 (in Chinese with English abstract). 
565

566

567

568

569

570

571

572

573

574

575

576

577

578

579

580

581

582

583

584

585

Cline, J.S., Bodnar, R.J., 1994. Direct evolution of brine from a crystallizing silicic melt at the Questa, New Mexico, molybdenum deposit. Econ. Geol. 89, 1780-1802.

Cogne, J.P., Kravchinsky, V.A., Halim, N., Hankard, F., 2005. Late Jurassic-Early Cretaceous closure of the Mongol-Okhotsk Ocean demonstrated by new Mesozoic palaeomagnetic results from the Trans-Baikal area (SE Siberia). Geophys. J. Int. 163, 813-832.

Deng, X.H., Chen, Y.J., Santosh, M., Yao, J.M., 2013. Genesis of the 1.76 Ga Zhaiwa Mo-Cu and its link with the Xiong'er volcanics in the North China Craton: implications for accretionary growth along the margin of the Columbia supercontinent. Precambrian Res. 227, 337-348.

Du, A.D., Wu, S.Q., Sun, D.Z., Wang, S.X., Qu, W.J., Markey, R., Stein, H., Morgan, J., Malinovskiy, D., 2004. Preparation and certification of Re-Os dating reference materials: Molybdenite HLP and JDC. Geostandard Geoanalytical Res. 28, 41-52.

Elhlou, S., Belousova, E., Griffin, W.L., Pearson, N.J., O'reilly, S.Y., 2006. Trace element and isotopic composition of GJ red zircon standard by laser ablation. Geochim. Cosmochim. Acta 70 (Suppl.), A158.

Engebretson, D.C., 1985. Relative motions between oceanic and continental plates in the Pacific basin. Geol. Soc. America Special Pap. 206, 1-60.

Enkin, R.J., Yang, Z.Y., Chen, Y., Courtillot, V., 1992. Palaeomagnetic constraints on the geodynamic history of the major blocks of china from the Permian to the present. $\mathrm{J}$ Geophys. Res-Sol. Ea. 97, 13953-13989. 
Farmer, G.L., Depaolo, D.J., 1984. Nd and Sr isotopic studies of unmineralized and Cu-mineralized and Mo-mineralized granite in the Precambrian craton. J. Geophy. Res. 89, 141-160.

Fu, R.Z., Kan, X.S., Meng, Z.J., Wang, J.P., 2011. Geological characteristics of Chalukou porphyry molybdenum polymetallic deposits, Daxinganling, Heilongjiang Province. Miner. Explor. 2, 223-240 (in Chinese).

Ge, W.C., Chen, J.S., Yang, H., Zhao, G.C., Zhang, Y.L., Tian, D.X., 2015. Tectonic implications of new zircon U-Pb ages for the Xinghuadukou Complex, Erguna Massif, northern Great Xing’an Range, NE China. J. Asian Earth Sci. 106, 169-185.

Griffin, W.L., Pearson, N.J., Belousova, E., Jackson, S.E., van Achterbergh, E., O’Reilly, S.Y., Shee, S.R., 2000. The Hf isotope composition of cratonic mantle: LAM-MC-ICPMS analysis of zircon megacrysts in kimberlites. Geochim. Cosmochim. Acta 64, 133-147.

Griffin, W.L., Wang, X., Jackson, S.E., Pearson, N.J., O'Reilly, S.Y., Xu, X., Zhou, X., 2002. Zircon chemistry and magma mixing, SE China: in-situ analysis of Hf isotopes, Tonglu and Pingtan igneous complexes. Lithos 61, 237-269.

Han, G.Q., Liu, Y.J., Neubauer, F., Genser, J., Li, W., Zhao, Y.L., Liang, C.Y., 2011. Origin of terranes in the eastern Central Asian Orogenic Belt, NE China: U-Pb ages of detrital zircons from Ordovician-Devonian sandstones, north Da Xing'an Mts. Tectonophysics 511, 109-124. 
HBGMR (Heilongjiang Bureau of Geology and Mineral Resources). 1993. Regional Geology of Heilongjiang Province. Geological Publishing House, Beijing, pp. 1-734 (in Chinese with English abstract).

Hu, Z.C., Liu, Y.S., Gao, S., Liu, W.G., Yang, L., Zhang, W., Tong, X.R., Lin, L., Zong, K.Q., Li, M., Chen, H.L., Zhou, L., Yang, L., 2012. Improved in situ Hf isotope ratio analysis of zircon using newly designed $\mathrm{X}$ skimmer cone and Jet sample cone in combination with the addition of nitrogen by laser ablation multiple collector ICP-MS. J. Anal. At. Spectrom. 27, 1391-1399.

IMBGMR (Inner Mongolian Bureau of Geology and Mineral Resources). 1991. Regional Geology of Inner Mongolia. Geological Publishing House, Beijing, pp. 1-725 (in Chinese with English abstract).

Kerrich, R., Goldfarb, R., Groves, D., Garwin, S., 2000. The geodynamics of world-class gold deposits: Characteristics, space-time distributions, and origins. Rev. Econ. Geol. 13, $501-551$.

Klemm, L.M., Pettke, T., Heinrich, C.A., 2008. Fluid and source magma evolution of the Questa porphyry Mo deposit, New Mexico, USA. Miner. Depos. 43, 533-552.

Kravchinsky, V.A., Cogne, J.P., Harbert, W.P., Kuzmin, M.I., 2002. Evolution of the Mongol-Okhotsk Ocean as constrained by new palaeomagnetic data from the Mongol-Okhotsk suture zone, Siberia. Geophys. J. Int. 148, 34-57.

Lawley, C.J.W., Richard, J.P., Anderson, R.G., Creaser, R.A., Heaman, L.M., 2010. Geochronology and geochemistry of the MAX porphyry Mo deposit and its relationship 

Geol. 105, 1113-1142.

Li, N., Sun, Y., Li, J., Li, W., 2007. Molybdenite Re/Os isochron age of the Wunugetu Shan porphyry $\mathrm{Cu} / \mathrm{Mo}$ deposit, Inner Mongolia and its implication for metallogenic geodynamics. Acta Petrol. Sin. 23, 2881-2888 (in Chinese with English abstract).

Li, N., Ulrich, T., Chen, Y.J., Thompson, T.B., Peace, V., Pirajno, F., 2012a. Fluid evolution of the Yuchiling porphyry Mo deposit, East Qinling, China. Ore Geol. Rev. 48, 442-459.

Li, N., Chen, Y.J., Ulrich, T., Lai, Y., 2012b. Fluid inclusion study of the Wunugetu Cu-Mo deposit, Inner Mongolia, China. Miner. Depos. 47(5), 467-482.

Li, N., Chen, Y.J., Pirajno, F., Ni, Z.Y., Sun, Y.L., 2013. Timing of the Yuchiling giant porphyry Mo system, eastern Qinling, central China, and implications for ore genesis. Miner. Depos. 48, 505-524.

Li, Z.Z., Qin, K.Z., Li, G.M., Ishihara, S., Jin, L.Y., Song, G.X., Meng, Z.J., 2014. Formation of the giant Chalukou porphyry Mo deposit in northern Great Xing'an Range, NE China: Partial melting of the juvenile lower crust in intra-plate extensional environment. Lithos 202, 138-156.

Liu, Y.S., Gao, S., Hu, Z.C., Gao, C.G., Zong, K.Q., Wang, D.B., 2010. Continental and oceanic crust recycling-induced melt-peridotite interactions in the Trans-North China Orogen: $\mathrm{U}-\mathrm{Pb}$ dating, $\mathrm{Hf}$ isotopes and trace elements in zircon s of mantle xenoliths. J. Petrol. 51, 537-571.

Liu, Y.F., Nie, F.J., Sun, Z.J., Lv, K.P., Zhang, K., Liu, Y., 2011. Discovery of Chalukou super large scale molybdenum polymetallic deposit, Northern Daxing'anlin Mountain, 

abstract).

651

652

653

654

655

656

657

658

659

660

661

662

663

664

665

666

667

668

669

Liu, J., Mao, J.W., Wu, G., Wang, F., Luo, D.F., Hu, Y.Q., 2014a. Zircon U-Pb and molybdenite Re-Os dating of the Chalukou porphyry Mo deposit in the northern Great Xing’an Range, China, and its geological significance. J. Asian Earth Sci. 79, 696-709.

Liu, J., Mao, J.W., Wu, G., Wang, F., Luo, D.F., Hu, Y.Q., Li, T.G., 2014b. Fluid inclusions and $\mathrm{H}-\mathrm{O}-\mathrm{S}-\mathrm{Pb}$ isotope systematics of the Chalukou giant porphyry Mo deposit, Heilongjiang Province, China. Ore Geol. Rev. 59, 83-96.

Liu, J., Mao, J.W., Wu, G., Wang, F., Luo, D.F., Hu, Y.Q., 2015. Geochemical signature of the granitoids in the Chalukou giant porphyry Mo deposit in the Heilongjiang Province, NE China. Ore Geol. Rev. 64, 35-52.

Ludington, S., Plumlee, G.S., 2009. Climax-type porphyry molybdenum deposits. U.S. Geological Survey Open-File Report 2009-1215, 1-16.

Ludwig, K.R., 2003. ISOPLOT 3.00: A Geochronological Toolkit for Microsoft Excel. Berkeley Geochronology Center, California, Berkeley, pp. 39.

Lv, K.P., Han, L., Zhang, J.N., 2010. Geological characteristics and prospecting symbol of Chalukou Mo deposit. Sci. Technol. Inform. Heilongjiang, 21, 31 (in Chinese).

Markey, R., Stein, H., Morgan, J., 1998. Highly precise Re-Os dating for molybdenite using alkaline fusion and NTIMS. Talanta 45, 935-946.

Metelkin, D.V., Gordienko, I.V., Klimuk, V.S., 2007. Paleomagnetism of Upper Jurassic basalts from Transbaikalia: new data on the time of closure of the Mongol-Okhotsk 

825-834.

672 Meyer, C., 1981. Ore-forming processes in geologic history. Econ. Geol. 75th Anniversary 673 Volume, 6-41.

674 Meyer, C., 1988. Ore deposits as guides to the geologic history of the Earth. Annual Rev. 675 Earth Plane. Sci. 16, 147-171.

676

678

679

680

681

682

683

684

685

686

687

688

689

690

691
Mi, M., Chen, Y.J., Yang, Y.F., Wang, P., Li, F.L., Wan, S.Q., Xu, Y.L., 2015. Geochronology and geochemistry of the giant Qian'echong Mo deposit, Dabie Shan, eastern China: Implications for ore genesis and tectonic setting. Gondwana Res. 27(3), $1217-1235$.

Miao, L.C., Liu, D.Y., Zhang, F.Q., Fan, W.M., Shi, Y.R., Xie, H.Q., 2007. Zircon SHRIMP $\mathrm{U}-\mathrm{Pb}$ ages of the "Xinghuadukou Group" in Hanjiayuanzi and Xinlin areas and the “Zhalantun Group” in Inner Mongolia, Da Hinggan mountains. Chin. Sci. Bull. 52, 1112-1134 (in Chinese with English Abstract).

Misra, K.C., 2000. Understanding mineral deposits. Springer Science \& Business Media, $1-845$.

Mitchell, A.H.G., Garson, M.S., 1981. Mineral deposits and global tectonic settings. London: Academic, 1-405.

Nie, F.J., Sun, Z.J., Chao, L., Liu, Y.F., Lv, K.P., Zhang, K., Liu, Y., 2011. Re-Os isotopic dating of molybdenite separates from Chalukou porphyry Mo polymetallic deposit in Heilongjiang Province. Miner. Depos. 40(5), 828-836 (in Chinese with English Abstract). 
Nie, F.J., Sun, Z.J., Liu, Y.F., Lv, K.P., Zhao, Y.A., Cao, Y., 2013. Mesozoic multiple magmatic activities and molybdenum mineralization in the Chalukou ore district, Da Hinggan Mountains. Geol. China 40(5), 273-286 (in Chinese with English Abstract).

Pettke, T., Oberli, F., Heinrich, C.A., 2010. The magma and metal source of giant porphyry-type ore deposits, based on lead isotope microanalysis of individual fluid inclusions. Earth Plant. Sci. Lett. 296, 267-277.

Pirajno, F., 2009. Hydrothermal processes and mineral systems. Geological Survey of Western Australia: Springer, Berlin (1250 pp.).

Pirajno, F., Zhou, T.F., 2015. Intracontinental porphyry and porphyry-skarn mineral systems in eastern China: scrutiny of a special case “made-in-China”. Econ. Geol. 110(3), 603-629.

Pirajno, F., 2016. A classification of mineral systems, overviews of plate tectonic margins and examples of ore deposits associated with convergent margins. Gondwana Res. doi: http://dx.doi.org/10.1016/j.gr.2015.08.013

Qi, J.P., Chen, Y.J., Franco, P., 2005. Geological characteristics and tectonic setting of the epithermal deposits in the Northeast China. J. Mineral. Petrol. 25, 47-59 (in Chinese with English abstract).

Sawkins, F.J., 1984. Metal deposits in relation to plate tectonics. Berlin: Springer-Verlag, $1-325$.

Sawkins, F.J., 1990. Metal deposits in relation to plate tectonics (2nd edition). NewYork: Springer-Verlag, 1-461. 
Seedorff, E., Einaudi, M., 2004a. Henderson porphyry molybdenum system, Colorado: I. Sequence, abundance of hydrothermal mineral assemblages, flow paths of evolving fluids, evolutionary style. Econ. Geol. 99, 3-37.

Seedorff, E., Einaudi, M., 2004b. Henderson porphyry molybdenum system, Colorado: II. Decoupling of introduction, deposition of metals during geochemical evolution of hydrothermal fluids. Econ. Geol. 99, 39-72.

Seedorff, E., Dilles, J.H., Proffett, J.M., Einaudi, M.T., Zurcher, L., Stavast, W.J.A., Johnson, D.A., Barton, M.D., 2005. Porphyry deposit: characteristics and origin of hypogene features. Econ. Geol. 100, 251-298.

Segal, I., Halicz, L., Platzner, I.T., 2003. Accurate isotope ratio measurements of ytterbium by multiple collection inductively coupled plasma mass spectrometry applying erbium and hafnium in an improved double external normalization procedure. J. Anal. At. Spectrom. 18, 1217-1223.

Selby, D., Nesbitt, B.E., Muehlenbachs, K., Prochaska, W., 2000. Hydrothermal alteration and fluid chemistry of the Endako porphyry molybdenite deposit, British Columbia. Econ. Geol. 95, 183-202.

Shao, J.A., Tang, K.D., 2015. Research on the Mesozoic ocean-continent transitional zone in the Northeast Asia and its implication. Acta Petrol. Sin. 31, 3147-3154 (in Chinese with English abstract).

Shao, J.A., Li, Y.F., Tang, K.D., 2013. Restoration of the orogenic processes of Zhangguangcai Range. Acta Petrol. Sin., 29, 2959-2970 (in Chinese with English abstract) 
Sillitoe, R.H., 1972. A plate tectonic model for the origin of porphyry copper deposits. Econ. Geol. 67, 184-197.

Sillitoe, R.H., 1980. Types of porphyry molybdenum deposits. Mining Mag. 142, 550-553.

Sillitoe, R.H., 2010. Porphyry copper systems. Econ. Geol. 105, 3-41.

Smoliar, M.I., Walker, R.J., Morgan, J.W., 1996. Re-Os ages of group IIA, IIIA, IVA and VIB iron meteorites. Science 271, 1099-1102.

Söderlund, U., Patchett, P.J., Vervoort, J.D., Isachsen, C.E., 2004. The ${ }^{176} \mathrm{Lu}$ decay constant determined by Lu-Hf and U-Pb isotope systematics of Precambrian mafic intrusions. Earth Planet. Sci. Lett. 219, 311-324.

Stein, H.J., 1985. A lead, strontium, and sulfur isotope study of Laramide-Tertiary intrusions and mineralization in the Colorado Mineral Belt with emphasis on Climax-type porphyry molybdenum systems plus a summary of other newly acquired isotopic and rare earth element data. Ph.D Thesis, Univ. Carolina, Chapel Hill, 500 pp.

Stein, H.J., Sundblad, K., Markey, R.J., Motuza, G., 1998. Re-Os ages for Archean molybdenite and pyrite, Kuittila-Kivisuo, Finland, and Proterozoic molybdenite, Kabeliai, Lithuania: testing the chronometer in a metamorphic and metasomatic setting. Miner. Depos. 33, 329-345.

Sui, Z.M., Ge, W.C., Wu, F.Y., Zhang, J.H., Xu, X.C., Cheng, R.Y., 2007. Zircon U-Pb ages, geochemistry and its petrogenesis of Jurassic granites in northeastern part of the Da Hinggan Mts. Acta Petrol. Sin. 23, 461-480 (in Chinese with English abstract).

Sun, D.Y., Wu, F.Y., Gao, S., Lu, X.P., 2005. Confirmation of two episodes of A-type granite emplacement during Late Triassic and Early Jurassic in the central Jilin Province, and 
their constraints on the structural pattern of Eastern Jilin-Heilongjiang area, China. Earth Sci. Front. 12, 263-275 (in Chinese with English abstract).

Sun, W., Chi, X.G., Zhao, Z., Pan, S.Y., Liu, J.F., Zhang, R., Quan, J.Y., 2014. Zircon geochronology constraints on the age and nature of 'Precambrian metamorphic rocks in the Xing'an block of Northeast China. Int. Geol. Rev. 56, 672-694.

Tang, J., Xu, W.L., Wang, F., Wang, W., Xu, M.J., Zhang, Y.H., 2014. Geochronology and geochemistry of Early-Middle Triassic magmatism in the Erguna Massif, NE China: Constraints on the tectonic evolution of the Mongol-Okhotsk Ocean. Lithos 184, 1-16.

Taylor, R.D., Hammarstrom, J.M., Piatak, N.M., Seal, R.R., 2012. Arc-related porphyry molybdenum deposit model. U.S. Geol. Survey Sci. Invest. Report 2010-5070-D, 1-64.

Wallace, S.R., 1995. SEG presidential address: the climax-type molybdenite deposits: what they are, where they are, and why they are. Econ. Geol. 90, 1359-1380.

Wang, F., Zhou, X.H., Zhang, L.C., Ying, J.F., Zhang, Y.T., Wu, F.Y., Zhu, R.X., 2006. Late Mesozoic volcanism in the Great Xing'an Range (NE China): timing and implications for the dynamic setting of NE Asia. Earth Planet. Sci. Lett. 251, 179-198.

Wang, J., Zhang, J., Wang, S., Zhang, D., Qi, X., Wu, G., Zhang, P., 2009. Characteristics of fluid inclusions and metallogenetic geodynamical setting of the Taipinggou Mo deposit in Inner Mongolia, China. Acta Petrol. Sin. 25, 2621-2630 (in Chinese with English abstract).

Wang, P., Chen, Y.J., Fu, B., Yang, Y.F., Mi, M., Li, Z.L., 2014. Fluid inclusion and H-O isotope geochemistry of the Yaochong porphyry Mo deposit in Dabie Shan, China: A case study of porphyry systems in continental collision orogens. Int. J. Earth Sci. 103, 
Wang, P., Chen, Y.J., Wang, C.M., Zhu, X.F., Wang, S.X, 2016a. Genesis and tectonic setting of the giant Diyanqin'amu porphyry Mo deposit in Great Hingan Range, NE China: Constraints from U-Pb and Re-Os geochronology and Hf isotopic geochemistry. Ore Geol. Rev. doi: 10.1016/j.oregeorev.2016.03.017.

Wang, P., Wang, Y., Yang, Y.F., 2016b. Zircon U-Pb geochronology and isotopic geochemistry of the Tangjiaping Mo deposit, Dabie Shan, China: Implications for ore genesis and tectonic setting. Ore Geol. Rev. under revision.

Wiedenbeck, M., Alle, P., Corfu, F., Griffin, W.L., Meier, M., Oberli, F., Quadt, A.V., Roddick, J.C., Spiegel, W., 1995. Three natural zircon standards for U-Th-Pb, Lu-Hf, trace element and REE analyses. Geostandards Geoanalytical Res. 19, 1-23.

Wu, Y.B., Zheng, Y.F., 2004. Research on zircon genesis and its constrain on U-Pb age. Chin. Sci. Bull. 49, 1589-1604 (in Chinese).

Wu, F.Y., Jahn, B.M., Wilde, S.A., Luo, C.H., Yui, T.F., Lin, Q., Ge, W.C., Sun, D.Y., 2003. Highly fractionated I-type granites in NE China: geochronology and petrogenesis. Lithos 66, 241-273.

Wu, F.Y., Sun, D.Y., Ge, W.C., Zhang, Y.B., Grant, M.L., Wilde, S.A., Jahn, B.M., 2011. Geochronology of the Phanerozoic granitoids in northeastern China. J. Asian Earth Sci. $41,1-30$.

Wu, G., Chen, Y.C., Chen, Y.J., Zeng, Q.T., 2012. Zircon U-Pb ages of the metamorphic supracrustal rocks of the Xinghuadukou Group and granitic complexes in the Argun 
Wu, Y.S., Wang, P., Yang, Y.F., Xiang, N., Li, N., Zhou, K.F., 2014. Ore geology and fluid inclusion study of the Donggebi giant porphyry Mo deposit, Eastern Tianshan, NW China. Geol. J. 49(6), 559-573.

Xiong, S.F., He, M.C., Yao, S.Z., Cui, Y.B., Shi, G.Z., Ding, Z.J., Hu, X.L., 2015. Fluid evolution of the Chalukou giant Mo deposit in the northern Great Xing'an Range, NE China. Geol. J. 50, 720-738.

Xu, W.L., Pei, FP., Wang, F., Meng, E., Ji, W.Q., Yang, D.B., Wang, W., 2013. Spatial-temporal relationships of Mesozoic volcanic rocks in NE China: Constraints on and isotope geochemistry of the Qian’echong giant porphyry Mo deposit, Dabie Shan, porphyry Mo system, East Qinling, China. Ore Geol. Rev. 65, 148-164. Mongol-Okhotsk collisional orogeny in latest Jurassic-earliest Cretaceous. Gondwana 
820

821

822

823

824

825

Yang, Y.F., Wang, P., Chen, Y.J., Li, Y., 2016. Geochronology and geochemistry of the Tianmugou Mo deposit, Dabie Shan, eastern China: Implications for ore genesis and tectonic setting. Ore Geol. Rev. accepted.

Zartman, R.E., 1974. Lead isotopic provinces in cordillera of western United-States and their geologic significance. Econ. Geol. 69, 792-805.

Zhai, D.G., Liu, J.J., Wang, J.P., Peng, R.M., Wang, S.G., Li, Y.X., Chang, Z.Y., 2009. Re-Os isotopic chronology of Molybdenite from the Taipinggou porphyry type Molybdenum deposit in Inner Mongolia and its geological significance. Geoscience 23, 263-268 (in Chinese with English abstract).

Zhang, C., Li, N., 2014. Geology, geochemistry and tectonic setting of the Indosinian Mo deposits in southern Great Hinggan Range, NE China. Geol. J. 49, 537-558.

Zhang, J.H., Gao, S., Ge, W.C., Wu, F.Y., Yang, J.H., Wilde, S.A., Li, M., 2010. Geochronology of the Mesozoic volcanic rocks in the Great Xing’an Range, northeastern China: Implications for subduction-induced delamination. Chem. Geol. 276, 144-165.

Zhang, C., Li, N., Chen, Y.J., Zhao, X.C., 2013. Zircon U-Pb ages and Hf isotopic compositions of the intrusive rocks in the Xing'a Mo-Cu deposit, Inner Mongolia. Acta Petrol. Sin. 29, 217-230 (in Chinese with English abstract).

Zhao, X., Coe, R.S., Gilder, S.A., Frost, G.M., 1996. Palaeomagnetic constraints on the palaeogeography of China: Implications for Gondwanaland. Aust. J. Earth Sci. 43, $643-672$.

Zhong, J., Chen, Y.J., Pirajno, F., Chen, J., Li, J., Qi, J.P., Li N., 2014. Geology, geochronology, fluid inclusion and $\mathrm{H}-\mathrm{O}$ isotope geochemistry of the Luoboling 
844 Zhou, J.B., Wilde, S.A., 2013. The crustal accretion history and tectonic evolution of the NE

\section{Figure Captions}

848 Fig. 1 (A) Schematic map of main tectonic domains of Asia (modified after Chen et al., 2004, 2007). (B)

849 Tectonic sub-divisions of Northeast China and Far East Russia (modified after Zhou and Wilde, 2013).

850 (C) Geological map of the northern Great Hingan Range, showing the locations of porphyry

851 Mo-bearing deposits (modified after Chen et al., 2012; Qi et al., 2005).

Fig. 2 Sketch regional geological map of the Chalukou orefield, showing the locations of the east and west section (modified after Fu et al., 2011).

855

Fig. 3 (A) Geological map of the east section of the Chalukou Mo deposit. (B) Geological profile for

857 prospecting line No. 10 (modified after Liu et al., 2011).

858 Abbreviation: Q-K: quartz-potassic alteration zone; Q-S: quartz-sericite alteration zone; Agl: argillization zone; Pro: propylitization zone. 
861 Fig. 4 Photographs showing ore petrography of the Chalukou Mo deposit.

862 (A) monzogranite; (B) granite porphyry with slight alteration and sulfide precipitation; (C) the

863 explosive breccias with clasts of granite porphyry and monzogranite; (D) medium-coarse grained

864 texture of the monzogranite; (E) phenocrysts of K-feldspar, plagioclase and quartz in granite porphyry;

865 (F) bladed molybdenite; (G) quartz-molybdenite-pyrite veinlet; (H) disseminated molybdenite; (I) the

866 potassic alteration where plagioclase is replaced by K-feldspar; (J) the quartz-sericite alteration where

867 sericite coexists with quartz and pyrite; (K) the silicification represented by abundant fine-grained

868 hydrothermal quartz; (L) the argillization, with mineral association of chlorite, kaolinite, fluorite and

869 pyrite; (M) the propylitization as represented by mineral association of epidote and chlorite; (N)

870 quartz-molybdenite vein in the potassic altered granite porphyry; (O) Mo-dominated stockwork.

871 Abbreviations: Bi: biotite, Chl: chlorite; Ep: epidote; Fl: fluorite; Kao: kaolinite; Kfs: K-feldspar; Mo:

872 molybdenite; Pl: plagioclase; Py: pyrite; Qz: quartz; Srt: sericite.

873

874 Fig. 5 Re-Os isochron plot and weighted average age for molybdenite samples from the Chalukou Mo 875 deposit.

877 Fig. 6 Cathodoluminescence (CL) images of zircons from monzogranite and granite porphyry. Small 878 and big circles represent spots of U-Pb dating and $\mathrm{Hf}$ isotopic analyses, respectively. 
Fig. 7 Zircon U-Pb isotope concordian diagrams and weighted average ages.

881

882

Fig. $8 \varepsilon \mathrm{Hf}(\mathrm{t})$ vs. $\mathrm{U}-\mathrm{Pb}$ age plot for zircons from various kinds of magmatic rocks.

883

Data are from this study, Li et al. (2014) and Liu et al. (2015); CHUR: chondrite uniform reservoir.

884

885

Fig. 9 Time framework of the magmatism and mineralization of the Chalukou porphyry Mo deposit.

886 Data are from this study, Li et al. (2014), Liu et al. (2014a) and Nie et al. (2011).

887

888

Fig. 10 Conceptual model showing the tectonic setting of the Chalukou Mo deposit at about 150 Ma.

889

890 Table Captions

891 Table 1 Re-Os isotope data for molybdenite from the Chalukou Mo deposit.

892

893 Table 2 LA-ICP-MS zircon U-Pb data for monzogranite and granite porphyry from the Chalukou 894 deposit.

895

896 Table 3 Zircon Lu-Hf data for monzogranite and granite porphyry from the Chalukou deposit. 
898 Table 4 Comparison of the Chalukou deposit with the ever-known porphyry Mo deposits sub-types. 

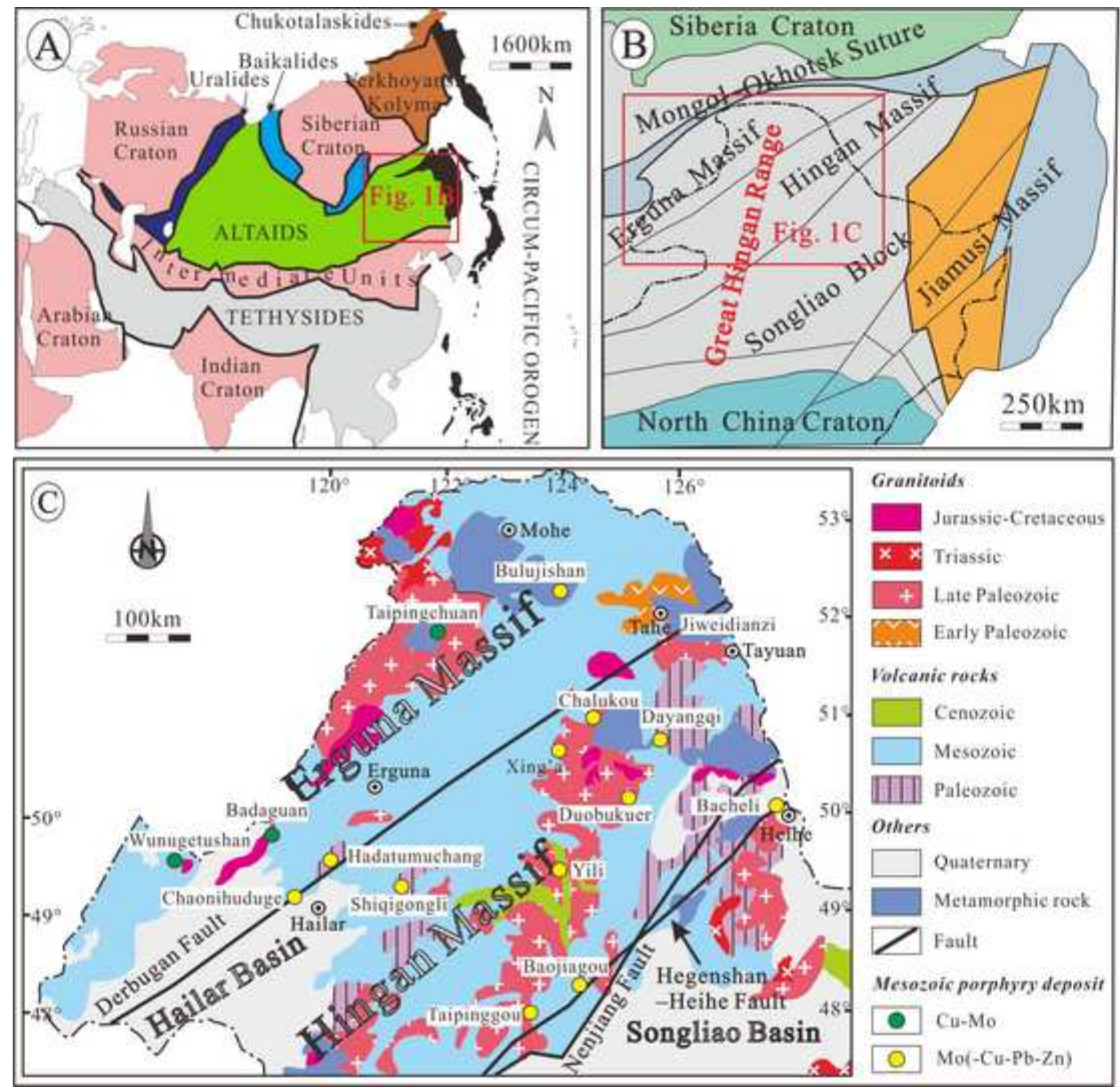


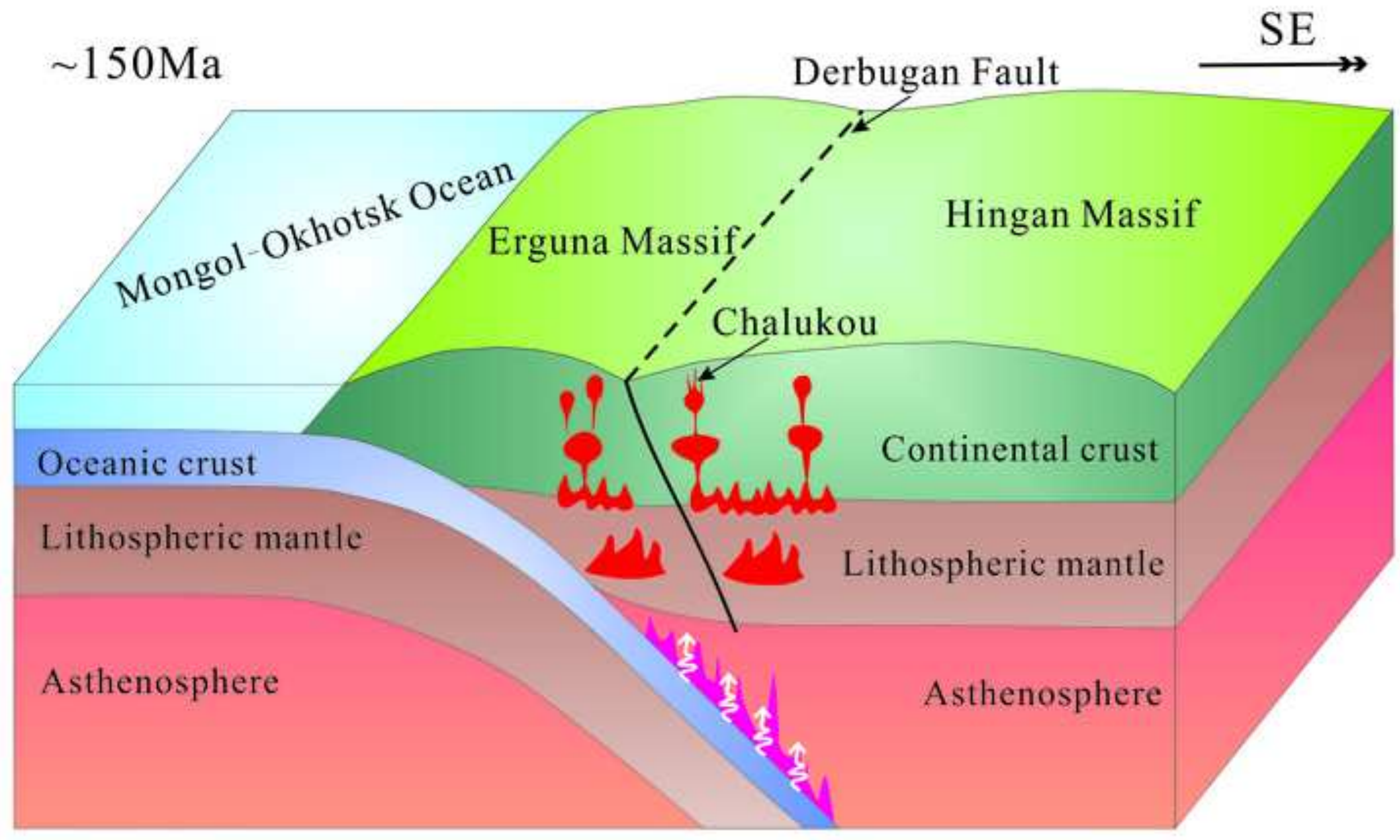




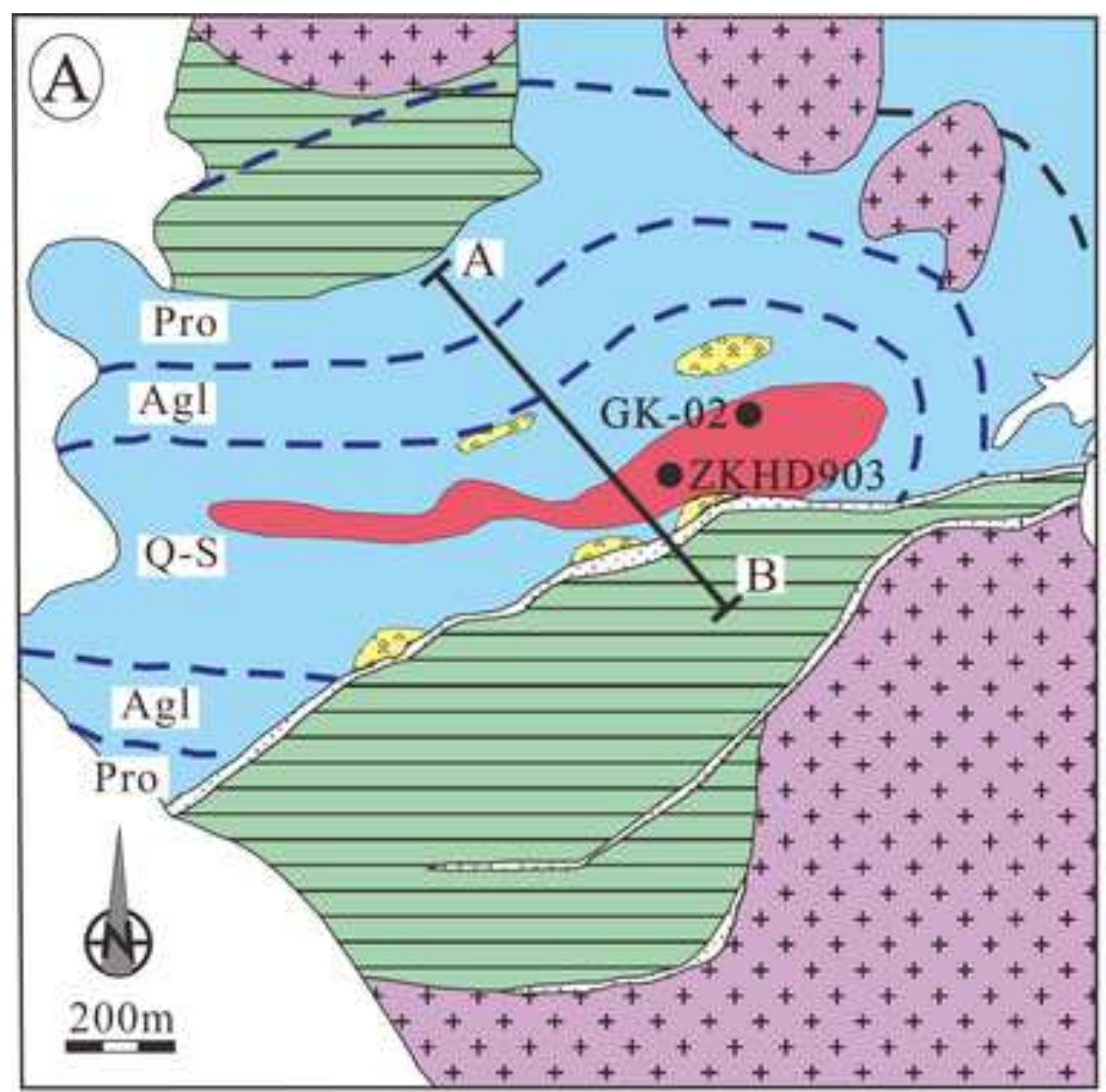

$\square$ Quaternary

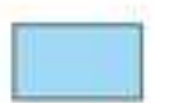

Jurassic volcanic -sedimentary rock Cambrian-Silurian metamorphic rock \lrcorner$\lrcorner\lrcorner$ Early Cretaceous $\perp\lrcorner$ diorite porphyry

$\begin{array}{ll}\times x & \begin{array}{l}\text { Late Jurassic } \\ \text { granite porphyry }\end{array}\end{array}$

${ }^{+}++$Jurassic

$+{ }_{+}^{+}$monzogranite

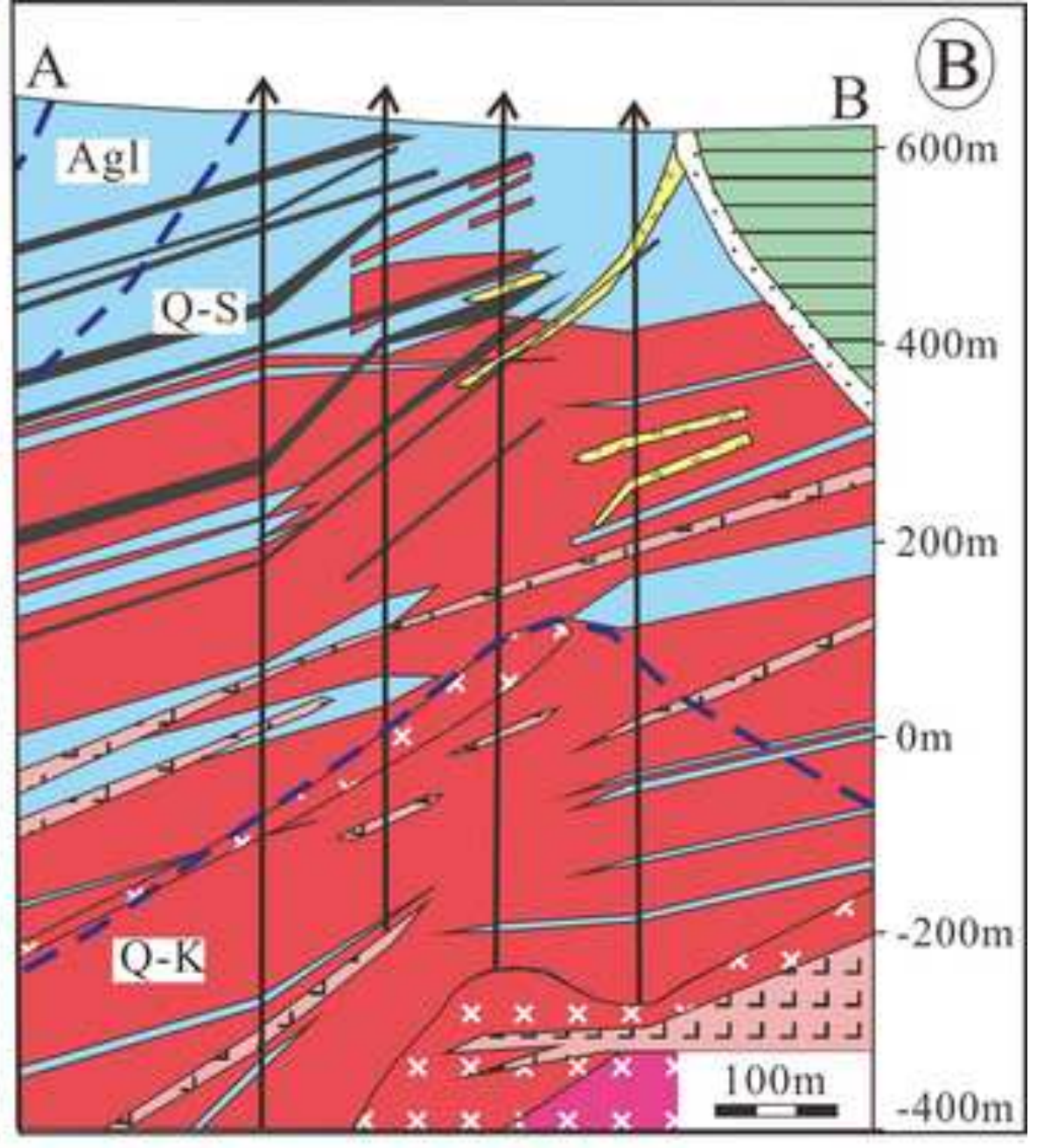

$\therefore A$ Breccias

F. Fracture zone

Mo orebody

- Alteration boundary

$\mathrm{Pb}-\mathrm{Zn}$ orebody

- Sample location 

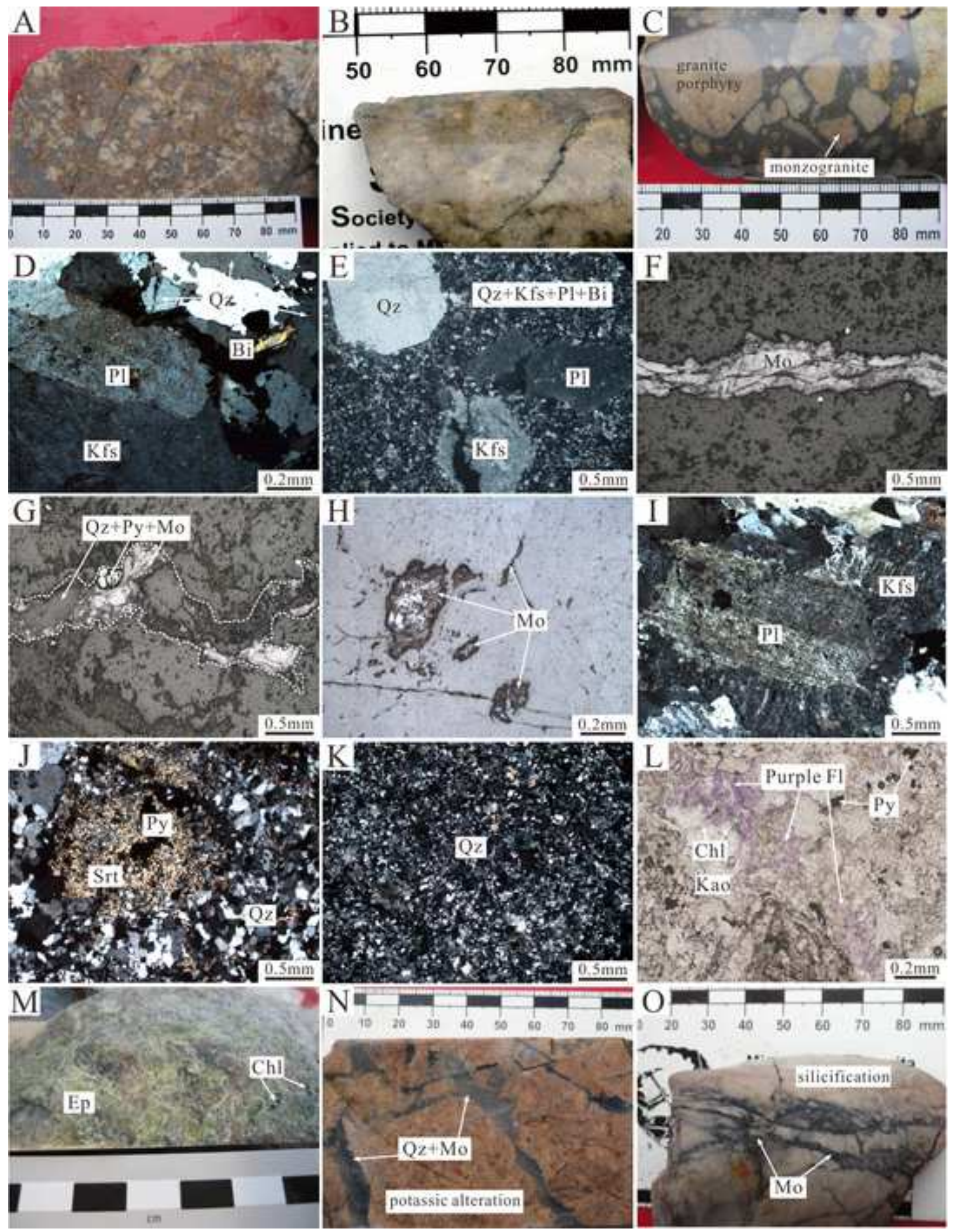


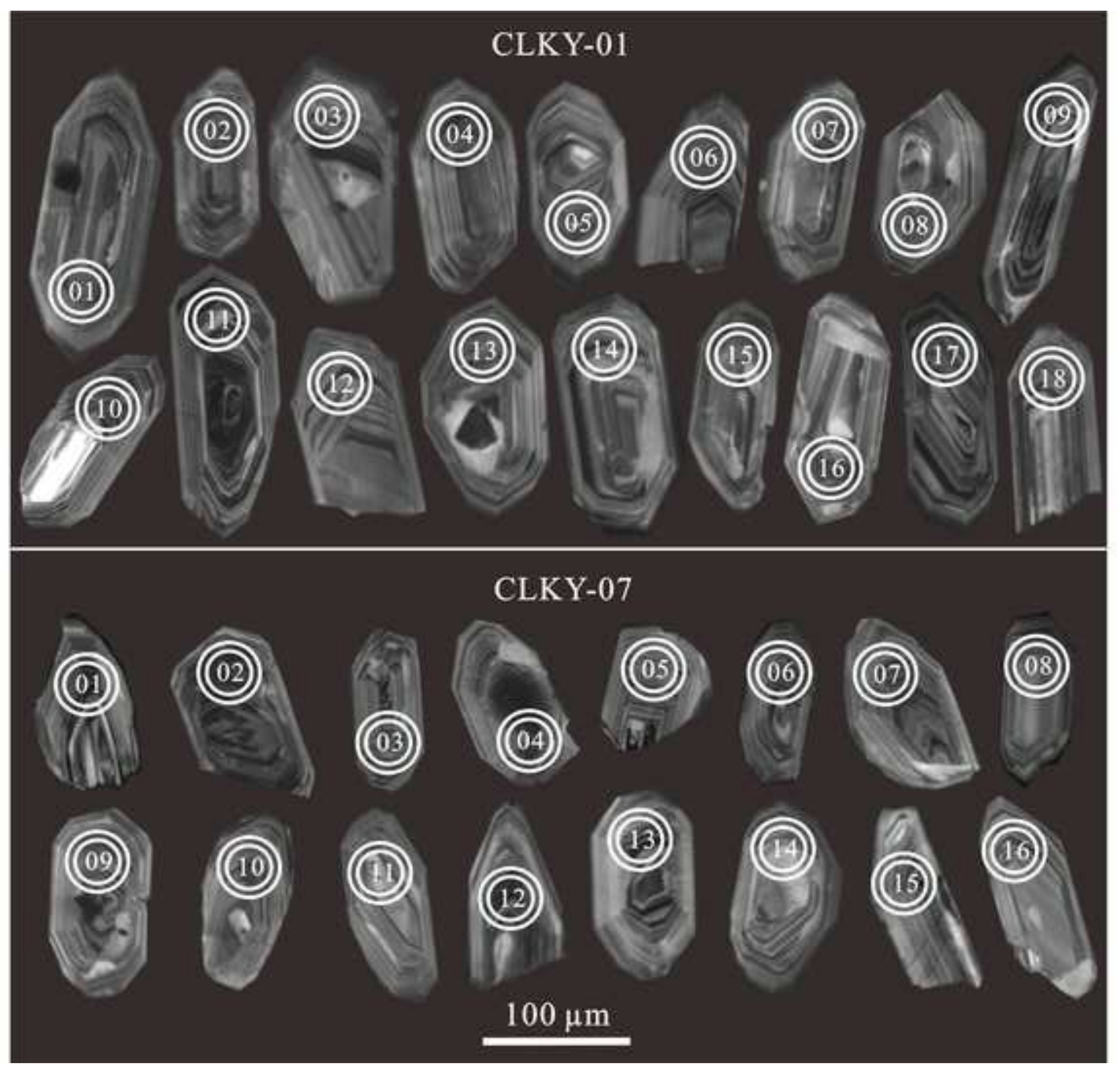



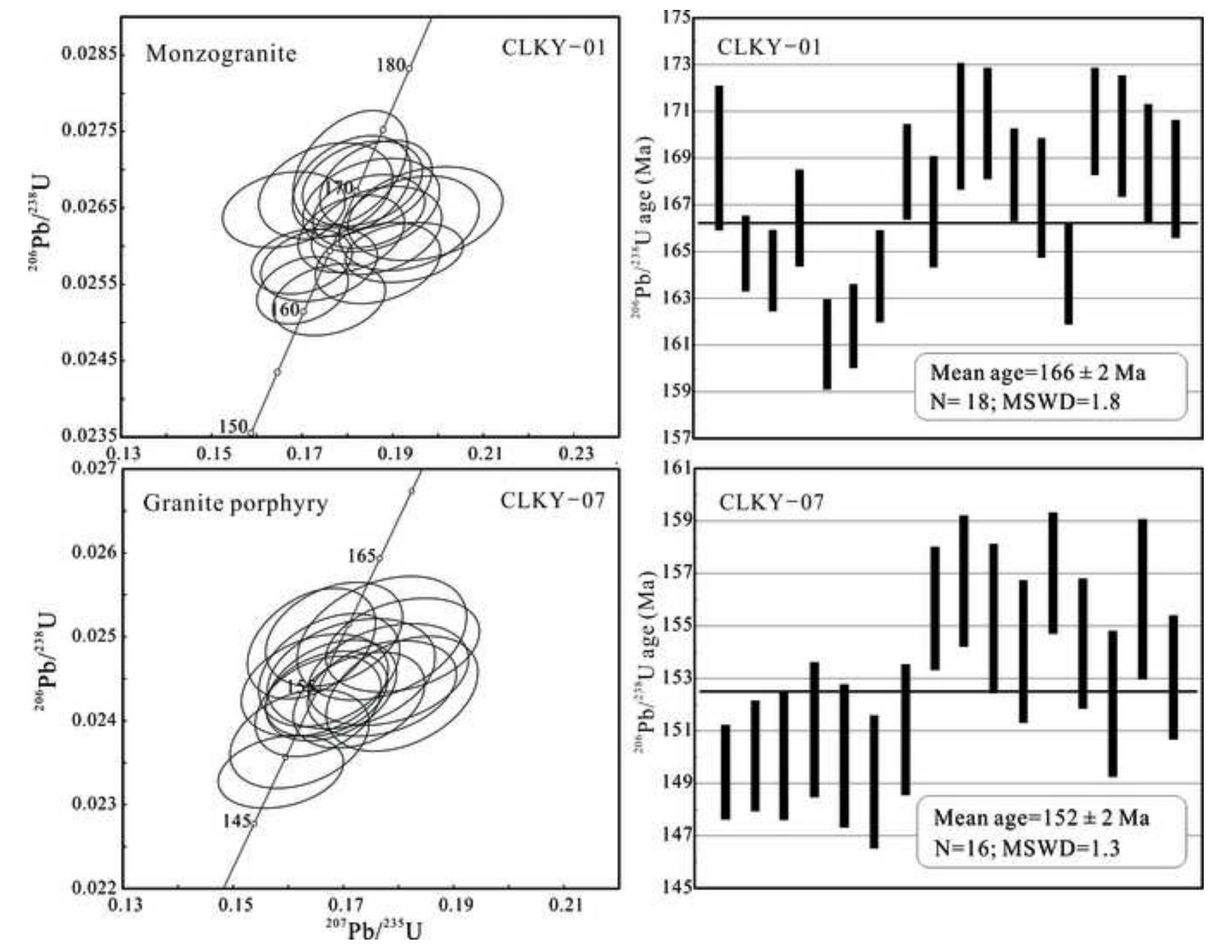

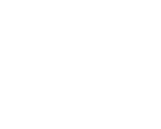$$
\text { st }
$$ 


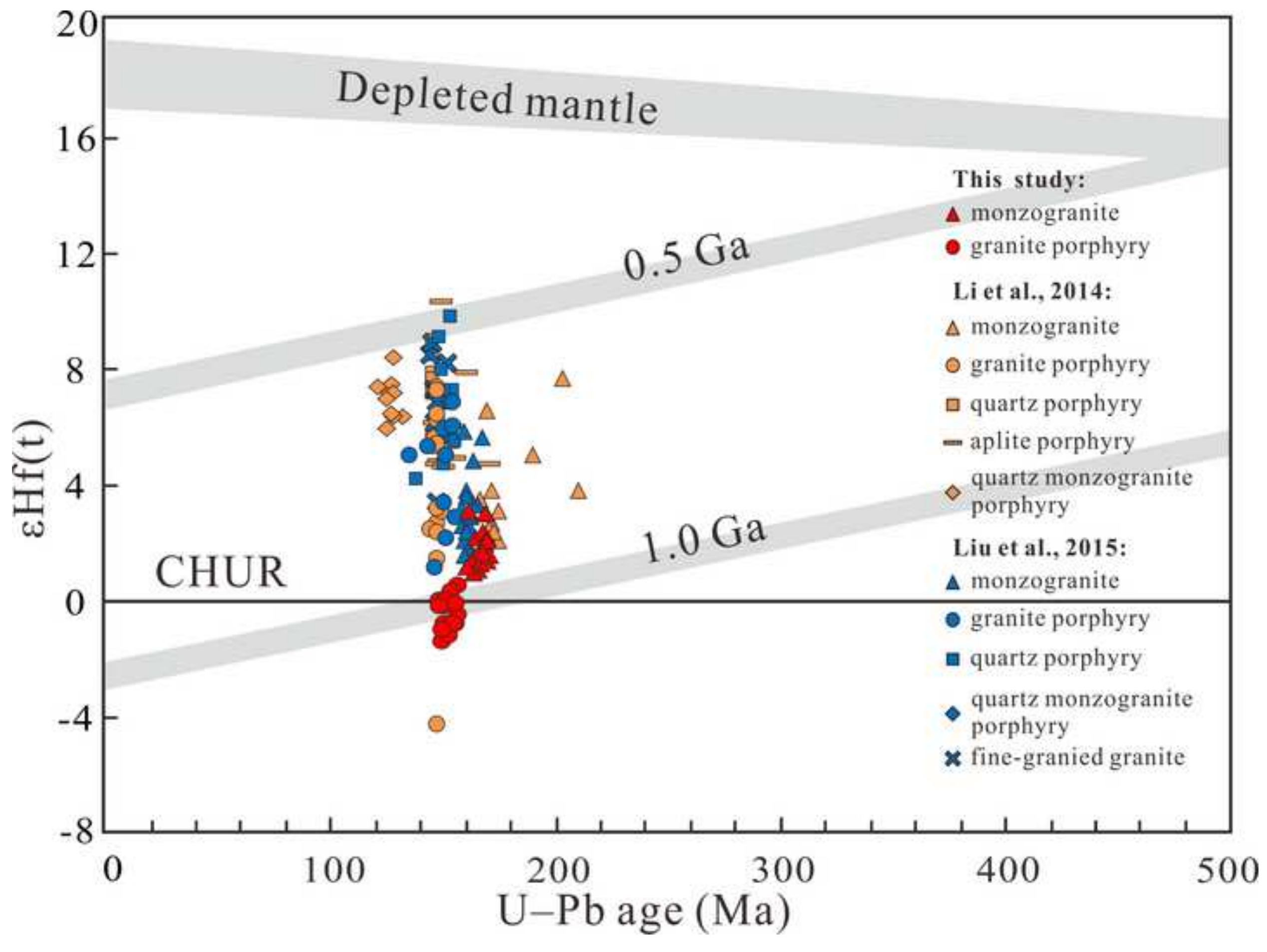




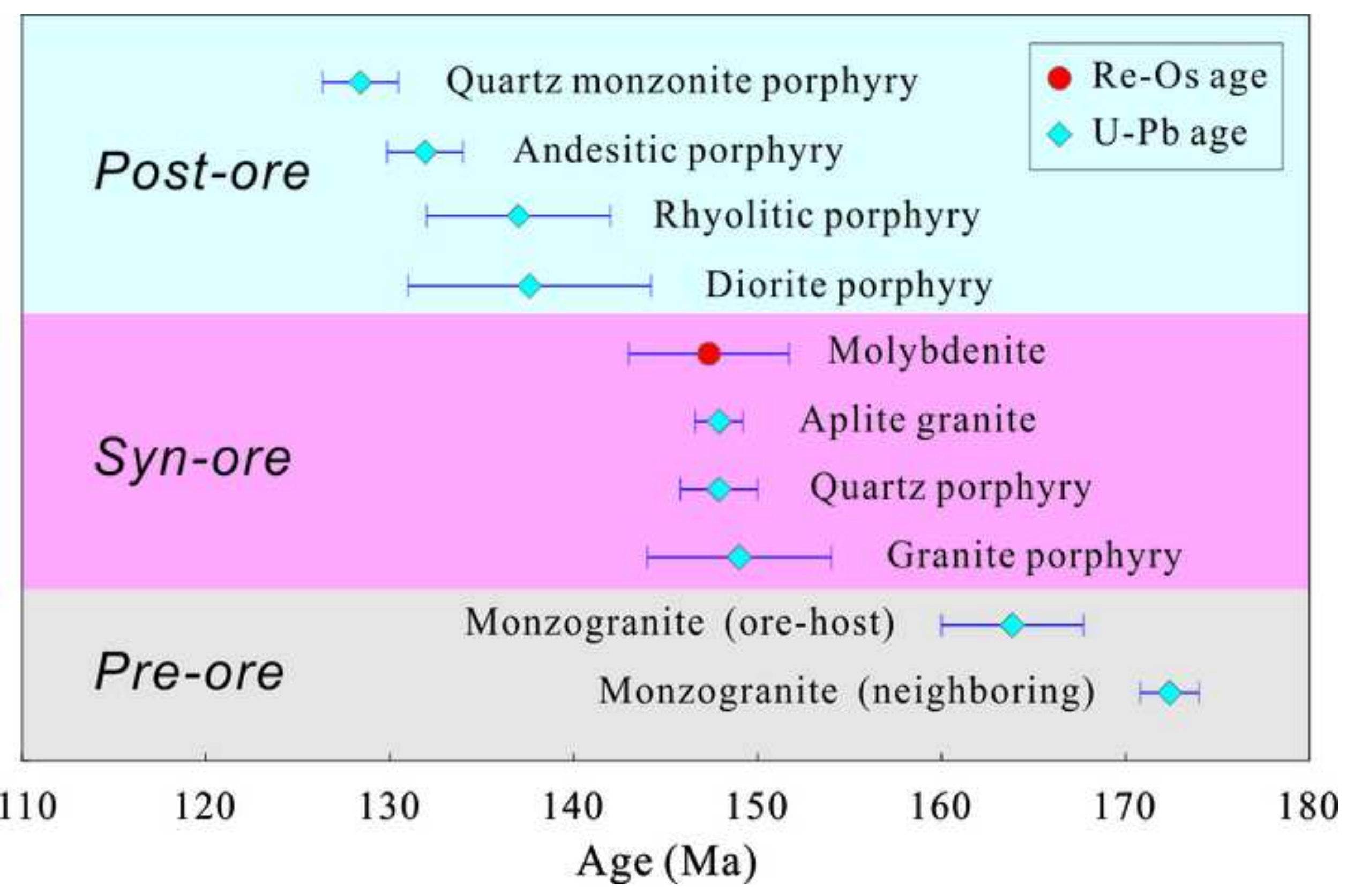




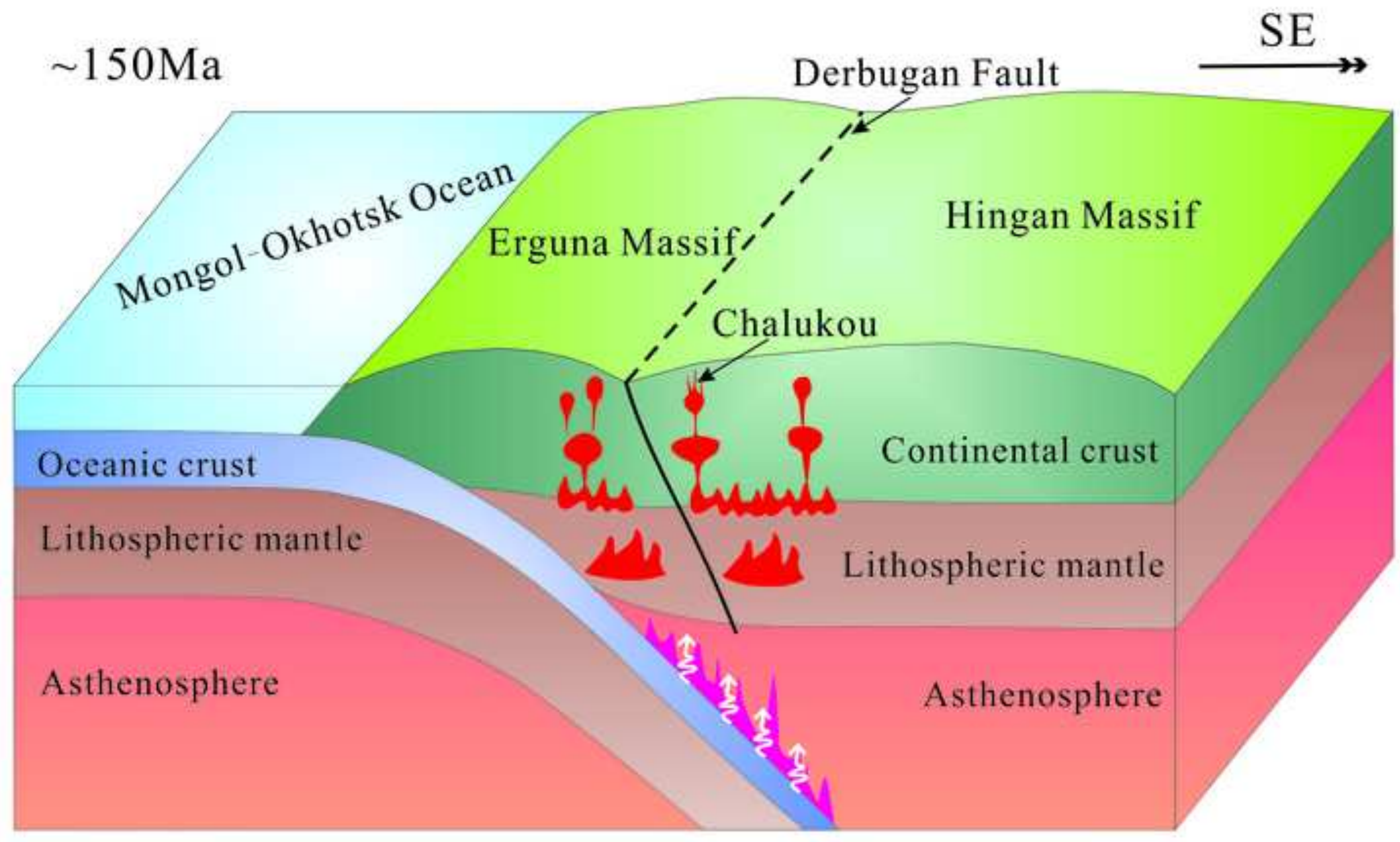


Table 1 Re-Os isotope data for molybdenite from the Chalukou Mo deposit.

\begin{tabular}{|c|c|c|c|c|c|c|c|c|c|c|c|c|}
\hline \multirow{2}{*}{ Sample } & \multirow{2}{*}{$\begin{array}{c}\text { Depth } \\
(\mathrm{m})\end{array}$} & \multirow{2}{*}{$\begin{array}{c}\text { Weight } \\
\text { (mg) }\end{array}$} & \multicolumn{2}{|c|}{$\operatorname{Re}(\mathrm{ppm})$} & \multicolumn{2}{|c|}{ Common Os (ppb) } & \multicolumn{2}{|c|}{${ }^{187} \operatorname{Re}(\mathrm{ppb})$} & \multicolumn{2}{|c|}{${ }^{187} \mathrm{Os}$ (ppb) } & \multicolumn{2}{|c|}{ Model age (Ma) } \\
\hline & & & Measured & $2 \sigma$ & Measured & $2 \sigma$ & Measured & $2 \sigma$ & Measured & $2 \sigma$ & Measured & $2 \sigma$ \\
\hline CLK-03 & 737 & 50.15 & 14.92 & 0.11 & 0.024 & 0.009 & 9379 & 70 & 23.13 & 0.20 & 148 & 2 \\
\hline CLK-04 & 744 & 50.26 & 3.14 & 0.03 & 0.003 & 0.009 & 2039 & 18 & 4.74 & 0.05 & 146 & 2 \\
\hline CLK-05 & 784 & 50.66 & 19.49 & 0.17 & 0.003 & 0.009 & 12450 & 110 & 30.55 & 0.24 & 150 & 2 \\
\hline CLK-06 & 850 & 50.03 & 17.86 & 0.13 & 0.005 & 0.024 & 11270 & 80 & 27.96 & 0.23 & 149 & 2 \\
\hline CLK-07 & 872 & 50.78 & 7.65 & 0.07 & 0.003 & 0.012 & 4809 & 44 & 11.49 & 0.09 & 146 & 2 \\
\hline CLK-10 & 1135 & 50.18 & 13.95 & 0.13 & 0.045 & 0.003 & 8670 & 82 & 21.12 & 0.17 & 147 & 2 \\
\hline CLK-11 & 1283 & 50.32 & 11.06 & 0.10 & 0.003 & 0.012 & 6954 & 62 & 16.84 & 0.14 & 147 & 2 \\
\hline
\end{tabular}

Note: Absolute uncertainties are stated at $2 \sigma$; Decay constant: $\lambda\left({ }^{187} \mathrm{Re}\right)=1.666 \times 10^{-11}$ year $^{-1}$ (Smoliar et al., 1996). 
Table $2 \mathrm{LA}-\mathrm{ICP}-\mathrm{MS}$ zircon $\mathrm{U}-\mathrm{Pb}$ data for monzogranite and granite porphyry from the Chalukou deposit

\begin{tabular}{|c|c|c|c|c|c|c|c|c|c|c|c|c|c|c|c|c|}
\hline \multirow{2}{*}{ Spot number } & \multicolumn{3}{|c|}{ Element (ppm) } & \multirow{2}{*}{${ }^{232} \mathrm{Th} /{ }^{238} \mathrm{U}$} & \multicolumn{6}{|c|}{ Isotope ratio } & \multicolumn{6}{|l|}{ Age (Ma) } \\
\hline & $\mathrm{Pb}^{*}$ & Th & $\mathrm{U}$ & & ${ }^{207} \mathrm{~Pb} /{ }^{206} \mathrm{~Pb}$ & $1 \sigma$ & ${ }^{207} \mathrm{~Pb} /{ }^{235} \mathrm{U}$ & $1 \sigma$ & ${ }^{206} \mathrm{~Pb} /{ }^{238} \mathrm{U}$ & $1 \sigma$ & ${ }^{207} \mathrm{~Pb} /{ }^{206} \mathrm{~Pb}$ & $1 \sigma$ & ${ }^{207} \mathrm{~Pb} /{ }^{235} \mathrm{U}$ & $1 \sigma$ & ${ }^{206} \mathrm{~Pb} /{ }^{238} \mathrm{U}$ & $1 \sigma$ \\
\hline CLKY-01-01 & 167 & 1413 & 1901 & 0.74 & 0.0490 & 0.0023 & 0.1810 & 0.0083 & 0.0270 & 0.0005 & 146 & 109 & 169 & 7 & 169 & 3 \\
\hline CLKY-01-02 & 174 & 1568 & 1962 & 0.80 & 0.0537 & 0.0023 & 0.1929 & 0.0085 & 0.0259 & 0.0003 & 367 & 100 & 179 & 7 & 165 & 2 \\
\hline CLKY-01-03 & 237 & 2215 & 2190 & 1.01 & 0.0477 & 0.0021 & 0.1704 & 0.0073 & 0.0258 & 0.0003 & 87 & 100 & 160 & 6 & 164 & 2 \\
\hline CLKY-01-04 & 175 & 1546 & 1838 & 0.84 & 0.0502 & 0.0021 & 0.1813 & 0.0077 & 0.0262 & 0.0003 & 211 & 98 & 169 & 7 & 166 & 2 \\
\hline CLKY-01-05 & 68.9 & 590 & 902 & 0.65 & 0.0515 & 0.0029 & 0.1856 & 0.0099 & 0.0265 & 0.0004 & 261 & 131 & 173 & 8 & 169 & 3 \\
\hline CLKY-01-06 & 215 & 2126 & 1951 & 1.09 & 0.0489 & 0.0020 & 0.1705 & 0.0067 & 0.0254 & 0.0003 & 143 & 90 & 160 & 6 & 162 & 2 \\
\hline CLKY-01-07 & 96 & 789 & 1756 & 0.45 & 0.0490 & 0.0024 & 0.1741 & 0.0085 & 0.0257 & 0.0003 & 146 & 114 & 163 & 7 & 164 & 2 \\
\hline CLKY-01-08 & 120 & 989 & 1565 & 0.63 & 0.0459 & 0.0025 & 0.1665 & 0.0089 & 0.0265 & 0.0003 & 45 & 93 & 156 & 8 & 168 & 2 \\
\hline CLKY-01-09 & 126 & 988 & 1523 & 0.65 & 0.0516 & 0.0026 & 0.1868 & 0.0095 & 0.0262 & 0.0004 & 265 & 121 & 174 & 8 & 167 & 2 \\
\hline CLKY-01-10 & 140 & 1103 & 1680 & 0.66 & 0.0490 & 0.0023 & 0.1813 & 0.0086 & 0.0268 & 0.0004 & 150 & 111 & 169 & 7 & 170 & 3 \\
\hline CLKY-01-11 & 161 & 1358 & 1960 & 0.69 & 0.0506 & 0.0022 & 0.1866 & 0.0081 & 0.0268 & 0.0004 & 220 & 99 & 174 & 7 & 170 & 2 \\
\hline CLKY-01-12 & 198 & 1670 & 2263 & 0.74 & 0.0505 & 0.0023 & 0.1851 & 0.0081 & 0.0264 & 0.0003 & 217 & 106 & 172 & 7 & 168 & 2 \\
\hline CLKY-01-13 & 87 & 637 & 1093 & 0.58 & 0.0545 & 0.0031 & 0.1940 & 0.0102 & 0.0263 & 0.0004 & 391 & 130 & 180 & 9 & 167 & 3 \\
\hline CLKY-01-14 & 97 & 822 & 1296 & 0.63 & 0.0474 & 0.0025 & 0.1756 & 0.0097 & 0.0267 & 0.0004 & 78 & 117 & 164 & 8 & 170 & 3 \\
\hline CLKY-01-15 & 139 & 1224 & 1588 & 0.77 & 0.0498 & 0.0024 & 0.1836 & 0.0087 & 0.0268 & 0.0004 & 187 & 108 & 171 & 7 & 171 & 2 \\
\hline CLKY-01-16 & 125 & 1027 & 1652 & 0.62 & 0.0529 & 0.0025 & 0.1871 & 0.0091 & 0.0258 & 0.0004 & 324 & 109 & 174 & 8 & 164 & 2 \\
\hline CLKY-01-17 & 264 & 2536 & 2374 & 1.07 & 0.0505 & 0.0023 & 0.1763 & 0.0081 & 0.0253 & 0.0003 & 217 & 106 & 165 & 7 & 161 & 2 \\
\hline CLKY-01-18 & 102 & 821 & 1171 & 0.70 & 0.0547 & 0.0032 & 0.1975 & 0.0112 & 0.0264 & 0.0004 & 398 & 130 & 183 & 10 & 168 & 3 \\
\hline CLKY-07-01 & 81 & 738 & 746 & 0.99 & 0.0489 & 0.0024 & 0.1590 & 0.0075 & 0.0234 & 0.0003 & 146 & 110 & 150 & 7 & 149 & 2 \\
\hline CLKY-07-02 & 75 & 590 & 960 & 0.62 & 0.0493 & 0.0022 & 0.1674 & 0.0074 & 0.0244 & 0.0003 & 161 & 106 & 157 & 6 & 150 & 2 \\
\hline CLKY-07-03 & 70 & 608 & 596 & 1.02 & 0.0497 & 0.0028 & 0.1688 & 0.0082 & 0.0251 & 0.0004 & 183 & 127 & 158 & 7 & 151 & 3 \\
\hline CLKY-07-04 & 57 & 510 & 536 & 0.95 & 0.0497 & 0.0027 & 0.1625 & 0.0084 & 0.0238 & 0.0004 & 189 & 125 & 153 & 7 & 150 & 2 \\
\hline CLKY-07-05 & 44 & 326 & 545 & 0.60 & 0.0500 & 0.0031 & 0.1720 & 0.0101 & 0.0246 & 0.0004 & 198 & 151 & 161 & 9 & 154 & 3 \\
\hline CLKY-07-06 & 82 & 645 & 649 & 0.99 & 0.0525 & 0.0027 & 0.1813 & 0.0092 & 0.0250 & 0.0004 & 306 & 119 & 167 & 8 & 157 & 2 \\
\hline CLKY-07-07 & 75 & 619 & 771 & 0.80 & 0.0543 & 0.0034 & 0.1775 & 0.0090 & 0.0244 & 0.0004 & 387 & 141 & 166 & 8 & 156 & 2 \\
\hline CLKY-07-08 & 41 & 328 & 420 & 0.78 & 0.0526 & 0.0029 & 0.1787 & 0.0097 & 0.0246 & 0.0004 & 309 & 121 & 167 & 8 & 157 & 3 \\
\hline CLKY-07-09 & 73 & 608 & 757 & 0.80 & 0.0512 & 0.0023 & 0.1733 & 0.0079 & 0.0243 & 0.0004 & 250 & 106 & 162 & 7 & 153 & 2 \\
\hline CLKY-07-10 & 58 & 458 & 565 & 0.81 & 0.0535 & 0.0027 & 0.1812 & 0.0092 & 0.0244 & 0.0005 & 350 & 115 & 169 & 8 & 155 & 3 \\
\hline CLKY-07-11 & 64 & 522 & 641 & 0.81 & 0.0502 & 0.0025 & 0.1683 & 0.0079 & 0.0244 & 0.0004 & 206 & 115 & 158 & 7 & 151 & 3 \\
\hline
\end{tabular}




\begin{tabular}{|c|c|c|c|c|c|c|c|c|c|c|c|c|c|c|c|c|}
\hline CLKY-07-12 & 63 & 508 & 720 & 0.71 & 0.0473 & 0.0022 & 0.1647 & 0.0077 & 0.0250 & 0.0004 & 65 & 107 & 155 & 7 & 150 & 3 \\
\hline CLKY-07-13 & 53 & 388 & 749 & 0.52 & 0.0500 & 0.0025 & 0.1659 & 0.0076 & 0.0242 & 0.0004 & 195 & 119 & 156 & 7 & 154 & 2 \\
\hline CLKY-07-14 & 49 & 406 & 510 & 0.80 & 0.0492 & 0.0025 & 0.1679 & 0.0085 & 0.0247 & 0.0004 & 167 & 120 & 158 & 7 & 152 & 3 \\
\hline CLKY-07-15 & 50 & 377 & 486 & 0.78 & 0.0526 & 0.0037 & 0.1775 & 0.0102 & 0.0250 & 0.0005 & 309 & 159 & 166 & 9 & 156 & 3 \\
\hline CLKY-07-16 & 69 & 579 & 689 & 0.84 & 0.0518 & 0.0050 & 0.1653 & 0.0089 & 0.0245 & 0.0004 & 276 & 220 & 155 & 8 & 149 & 3 \\
\hline
\end{tabular}


Table 3 Zircon Lu-Hf data for monzogranite and granite porphyry from the Chalukou deposit

\begin{tabular}{|c|c|c|c|c|c|c|c|c|c|c|c|}
\hline Rock & Spot number & Age (Ma) & ${ }^{176} \mathrm{Yb} /{ }^{177} \mathrm{Hf}$ & ${ }^{176} \mathrm{Lu} /{ }^{177} \mathrm{Hf}$ & ${ }^{176} \mathrm{Hf} /{ }^{177} \mathrm{Hf}$ & $1 \sigma$ & $\varepsilon \mathrm{Hf}(0)$ & $\varepsilon \mathrm{Hf}(\mathrm{t})$ & $\mathrm{T}_{\mathrm{DM} 1}(\mathrm{Ma})$ & $\mathrm{T}_{\mathrm{DM} 2}(\mathrm{Ma})$ & $\overline{\mathrm{f}_{\mathrm{Lu} / \mathrm{Hf}}}$ \\
\hline \multirow[t]{18}{*}{ monzogranite } & CLKY-01-01 & 169 & 0.026720 & 0.001296 & 0.282753 & 0.000010 & -0.7 & 2.9 & 713 & 1027 & -0.96 \\
\hline & CLKY-01-02 & 165 & 0.026050 & 0.001185 & 0.282732 & 0.000012 & -1.4 & 2.1 & 740 & 1076 & -0.96 \\
\hline & CLKY-01-03 & 164 & 0.027953 & 0.001171 & 0.282713 & 0.000009 & -2.1 & 1.4 & 767 & 1119 & -0.96 \\
\hline & CLKY-01-04 & 166 & 0.027701 & 0.001127 & 0.282701 & 0.000010 & -2.5 & 1.0 & 783 & 1145 & -0.97 \\
\hline & CLKY-01-05 & 169 & 0.013860 & 0.000575 & 0.282723 & 0.000009 & -1.7 & 1.9 & 741 & 1090 & -0.98 \\
\hline & CLKY-01-06 & 162 & 0.033734 & 0.001269 & 0.282761 & 0.000009 & -0.4 & 3.0 & 701 & 1013 & -0.96 \\
\hline & CLKY-01-07 & 164 & 0.038773 & 0.001548 & 0.282714 & 0.000009 & -2.1 & 1.4 & 773 & 1120 & -0.95 \\
\hline & CLKY-01-08 & 168 & 0.021656 & 0.000990 & 0.282736 & 0.000008 & -1.3 & 2.3 & 731 & 1064 & -0.97 \\
\hline & CLKY-01-09 & 167 & 0.019700 & 0.000845 & 0.282706 & 0.000008 & -2.3 & 1.2 & 770 & 1131 & -0.97 \\
\hline & CLKY-01-10 & 170 & 0.015468 & 0.000583 & 0.282726 & 0.000008 & -1.6 & 2.0 & 737 & 1082 & -0.98 \\
\hline & CLKY-01-11 & 170 & 0.035497 & 0.001497 & 0.282709 & 0.000007 & -2.2 & 1.3 & 780 & 1127 & -0.95 \\
\hline & CLKY-01-12 & 168 & 0.035338 & 0.001433 & 0.282724 & 0.000011 & -1.7 & 1.8 & 757 & 1094 & -0.96 \\
\hline & CLKY-01-13 & 167 & 0.024508 & 0.001103 & 0.282721 & 0.000008 & -1.8 & 1.7 & 754 & 1099 & -0.97 \\
\hline & CLKY-01-14 & 170 & 0.018830 & 0.000856 & 0.282725 & 0.000010 & -1.7 & 2.0 & 744 & 1087 & -0.97 \\
\hline & CLKY-01-15 & 171 & 0.027456 & 0.001140 & 0.282712 & 0.000010 & -2.1 & 1.5 & 768 & 1117 & -0.97 \\
\hline & CLKY-01-16 & 164 & 0.038648 & 0.001652 & 0.282702 & 0.000011 & -2.5 & 0.9 & 793 & 1147 & -0.95 \\
\hline & CLKY-01-17 & 161 & 0.027588 & 0.001213 & 0.282705 & 0.000008 & -2.4 & 1.0 & 779 & 1139 & -0.96 \\
\hline & CLKY-01-18 & 168 & 0.013652 & 0.000604 & 0.282714 & 0.000008 & -2.1 & 1.6 & 754 & 1111 & -0.98 \\
\hline \multirow[t]{13}{*}{ granite porphyry } & CLKY-07-01 & 149 & 0.038355 & 0.001587 & 0.282685 & 0.000010 & -3.1 & 0.0 & 816 & 1194 & -0.95 \\
\hline & CLKY-07-02 & 150 & 0.030322 & 0.001343 & 0.282644 & 0.000010 & -4.5 & -1.4 & 869 & 1283 & -0.96 \\
\hline & CLKY-07-03 & 151 & 0.031465 & 0.001380 & 0.282661 & 0.000012 & -3.9 & -0.7 & 845 & 1245 & -0.96 \\
\hline & CLKY-07-04 & 150 & 0.023920 & 0.001089 & 0.282677 & 0.000014 & -3.4 & -0.2 & 816 & 1208 & -0.97 \\
\hline & CLKY-07-05 & 154 & 0.022550 & 0.001028 & 0.282653 & 0.000017 & -4.2 & -0.9 & 849 & 1259 & -0.97 \\
\hline & CLKY-07-06 & 157 & 0.021628 & 0.000935 & 0.282689 & 0.000008 & -2.9 & 0.4 & 796 & 1176 & -0.97 \\
\hline & CLKY-07-07 & 156 & 0.018212 & 0.000840 & 0.282655 & 0.000012 & -4.1 & -0.8 & 842 & 1252 & -0.97 \\
\hline & CLKY-07-08 & 157 & 0.024124 & 0.001077 & 0.282663 & 0.000014 & -3.9 & -0.5 & 836 & 1235 & -0.97 \\
\hline & CLKY-07-09 & 153 & 0.028556 & 0.001264 & 0.282648 & 0.000010 & -4.4 & -1.2 & 861 & 1272 & -0.96 \\
\hline & CLKY-07-10 & 155 & 0.031722 & 0.001471 & 0.282659 & 0.000013 & -4.0 & -0.7 & 850 & 1248 & -0.96 \\
\hline & CLKY-07-11 & 151 & 0.017699 & 0.000817 & 0.282674 & 0.000010 & -3.5 & -0.2 & 815 & 1212 & -0.98 \\
\hline & CLKY-07-12 & 150 & 0.033979 & 0.001447 & 0.282653 & 0.000010 & -4.2 & -1.1 & 858 & 1264 & -0.96 \\
\hline & CLKY-07-13 & 154 & 0.030519 & 0.001303 & 0.282686 & 0.000012 & -3.0 & 0.2 & 808 & 1187 & -0.96 \\
\hline
\end{tabular}




\begin{tabular}{lllllllllll} 
CLKY-07-14 & 152 & 0.033347 & 0.001402 & 0.282681 & 0.000015 & -3.2 & 0.0 & 817 & 1200 & -0.96 \\
CLKY-07-15 & 156 & 0.027290 & 0.001159 & 0.282674 & 0.000006 & -3.5 & -0.2 & 822 & 1212 & -0.97 \\
CLKY-07-16 & 149 & 0.026793 & 0.001252 & 0.282678 & 0.000010 & -3.3 & -0.2 & 818 & 1207 & -0.96 \\
\hline
\end{tabular}

Note: The following parameters were employed to the calculation: $\left({ }^{176} \mathrm{Lu} /{ }^{177} \mathrm{Hf}\right)_{\mathrm{CHUR}, ~}=0.0332$ and $\left({ }^{176} \mathrm{Hf} /{ }^{177} \mathrm{Hf}\right)_{\mathrm{CHUR}}, 0=0.282772$ (Blichert-Toft and Albarede., 1997$)$; $\left({ }^{176} \mathrm{Lu} /{ }^{177} \mathrm{Hf}\right)_{\mathrm{DM}, 0}=0.0384$ and $\left({ }^{176} \mathrm{Hf} /{ }^{177} \mathrm{Hf}\right)_{\mathrm{DM}, 0}=0.28325$ (Griffin et al., 2000); ${ }^{176} \mathrm{Lu}$ decay constant $\lambda=1.867 \times 10^{-11} / \mathrm{y}$ (Söderlund et al., 2004). 
Table 4 Comparison of the Chalukou deposit with the ever-known porphyry Mo deposits sub-types

\begin{tabular}{|c|c|c|c|c|c|}
\hline & Characteristics & Rift- or Climax-type & Subduction- or Endako-type & Collision- or Dabie-type & The Chalukou deposit \\
\hline \multirow[t]{3}{*}{$\begin{array}{l}\text { Ore-causative } \\
\text { intrusion }\end{array}$} & Rock type & $\begin{array}{l}\text { Granite porphyry, rhyolite } \\
\text { porphyry }\end{array}$ & $\begin{array}{l}\text { Quartz monzonite, granodiorite, } \\
\text { granite porphyry }\end{array}$ & $\begin{array}{l}\text { Multiple or simple intrusions of } \\
\text { (K-feldspar) granite, monzogranite }\end{array}$ & $\begin{array}{l}\text { Monzogranite, granite } \\
\text { porphyry }\end{array}$ \\
\hline & Occurrence & Stock, dyke & Stock, granite batholith & Stock, minor granite batholith & Stock, granite batholith \\
\hline & $\begin{array}{l}\text { Comagmatic } \\
\text { extrusion }\end{array}$ & Yes & Yes & None & Rhyolite, dacite \\
\hline \multirow{5}{*}{$\begin{array}{l}\text { Petrological } \\
\text { geochemistry }\end{array}$} & $\mathrm{F} / \mathrm{ppm}$ & $400-3185$, mostly $>1000$ & Low, 1251 (only one data) & High, mostly $>1500$ & Low \\
\hline & $\mathrm{Rb} / \mathrm{ppm}$ & $114-857$, mostly $>300$ & $58-240$, mostly $<200$ & $60-577$, mostly $100-400$ & 141-229 (Li et al., 2014) \\
\hline & $\mathrm{Sr} / \mathrm{ppm}$ & $2-260$, mostly $<100$ & $20-653$ & 9-791, mostly 100-700 & 20.7-92.8 (Li et al., 2014) \\
\hline & $\mathrm{Nb} / \mathrm{ppm}$ & $14-208$, mostly $>50$ & $5-18$, mostly $<15$ & 4-97, mostly 10-70 & 8.94-46.2 (Li et al., 2014) \\
\hline & $\mathrm{Zr} / \mathrm{ppm}$ & $76-306$, mostly $<120$ & $59-166$, mostly $>120$ & $1-266$, mostly $10-230$ & 88.6-289 (Li et al., 2014) \\
\hline \multirow[t]{5}{*}{ Mineralization } & Commodity & Mo-only, Mo-W, Mo-Sn & $\begin{array}{l}\mathrm{Mo} \pm \mathrm{Cu} \pm \mathrm{Pb} \pm \mathrm{Zn} \pm \mathrm{Ag} \\
\text { Mo-W, rare Mo-only }\end{array}$ & $\begin{array}{l}\text { Mo-only, Mo-W, Mo-Fe, } \mathrm{Mo} \pm \\
\mathrm{Pb} \pm \mathrm{Zn} \pm \mathrm{Ag}\end{array}$ & $\mathrm{Mo}-\mathrm{Pb}-\mathrm{Zn}$ \\
\hline & Orebody shape & Inverted cup, hemispheric & $\begin{array}{l}\text { Inverted cup, layered, circular, } \\
\text { lenticular, irregular }\end{array}$ & Sheet-like, lenticular, irregular & $\begin{array}{l}\text { Inverted cup, layered, } \\
\text { lenticular }\end{array}$ \\
\hline & Style & $\begin{array}{l}\text { Stockwork veinlets, } \\
\text { disseminations }\end{array}$ & $\begin{array}{l}\text { Stockwork veinlets, } \\
\text { disseminations and breccias }\end{array}$ & $\begin{array}{l}\text { Stockwork veinlets, minor } \\
\text { disseminations and breccias }\end{array}$ & $\begin{array}{l}\text { Stockwork veinlets, } \\
\text { disseminations and breccias }\end{array}$ \\
\hline & $\begin{array}{l}\text { Average Mo } \\
\text { ore grade/\% }\end{array}$ & $0.1-0.3$ & $0.03-0.20$ & $0.06-0.11$ & 0.11 \\
\hline & $\begin{array}{l}\text { Ore-associated } \\
\text { mineral }\end{array}$ & $\begin{array}{l}\text { Molybdenite, pyrite, } \\
\text { wolframite, cassiterite, stibnite, } \\
\text { chalcopyrite, fluorite, topaz, } \\
\text { sericite }\end{array}$ & $\begin{array}{l}\text { Molybdenite, pyrite, cassiterite, } \\
\text { scheelite, chalcopyrite, } \\
\text { sphalerite, galena, magnetite, } \\
\text { fluorite, sericite }\end{array}$ & $\begin{array}{l}\text { Molybdenite, pyrite, scheelite, } \\
\text { chalcopyrite, sphalerite, galena, } \\
\text { wolframite, fluorite, sericite, } \\
\text { K-feldspar, carbonates }\end{array}$ & $\begin{array}{l}\text { Molybdenite, sphalerite, } \\
\text { galena, pyrite, magnetite, } \\
\text { chalcopyrite }\end{array}$ \\
\hline
\end{tabular}




\begin{tabular}{|c|c|c|c|c|c|}
\hline Alteration & $\begin{array}{l}\text { Hydrothermal } \\
\text { alteration }\end{array}$ & $\begin{array}{l}\text { Potassic and phyllic alteration, } \\
\text { intense silicified and propylitic } \\
\text { alteration }\end{array}$ & $\begin{array}{l}\text { Potassic alteration, , intense } \\
\text { propylitic alteration, widespread } \\
\text { argillic alteration }\end{array}$ & $\begin{array}{l}\text { Intense potassic alteration, weak } \\
\text { phyllic and propylitic alteration, } \\
\text { showing unclear zonation }\end{array}$ & $\begin{array}{l}\text { Potassic and phyllic } \\
\text { alteration, intense } \\
\text { propylitic and argillic } \\
\text { alteration }\end{array}$ \\
\hline \multirow[t]{3}{*}{ Fluids } & Inclusion type & $\begin{array}{l}\text { Aqueous, brine, with or without } \\
\mathrm{CO}_{2}-\mathrm{H}_{2} \mathrm{O}\end{array}$ & $\begin{array}{l}\text { Aqueous, rare } \mathrm{CO}_{2}-\mathrm{H}_{2} \mathrm{O} \text {, with or } \\
\text { without brine }\end{array}$ & $\begin{array}{l}\text { Pure } \mathrm{CO}_{2}, \mathrm{CO}_{2}-\mathrm{H}_{2} \mathrm{O} \text {, aqueous, } \\
\text { lack of brine inclusions }\end{array}$ & $\begin{array}{l}\text { Aqueous, brine without } \\
\mathrm{CO}_{2} \text { (Liu et al., 2014b) }\end{array}$ \\
\hline & Original phase & $\begin{array}{l}\text { Low salinity liquid with } \\
\text { moderate to low } \mathrm{CO}_{2}\end{array}$ & $\begin{array}{l}\text { Low to moderate salinity liquid } \\
\text { with low } \mathrm{CO}_{2} \text { or without } \mathrm{CO}_{2}\end{array}$ & $\begin{array}{l}\text { High to moderate salinity liquid } \\
\text { with } \mathrm{CO}_{2} \text {-rich vapor }\end{array}$ & $\begin{array}{l}\text { Moderate salinity liquid } \\
\text { with minor low } \mathrm{CO}_{2} \text { (Liu et } \\
\text { al., 2014b) }\end{array}$ \\
\hline & Temperature $/{ }^{\circ} \mathrm{C}$ & $300-450$ & $250-450$ & $250-400$ & 234-511 (Liu et al., 2014b) \\
\hline $\begin{array}{l}\text { Metallogenic } \\
\text { age }\end{array}$ & & 5-50 Ma, mostly 20-35 Ma & 8-160 Ma, mostly 50-90 Ma & $110-158 \mathrm{Ma}$, mostly $130-150 \mathrm{Ma}$ & $149.7 \pm 2.4 \mathrm{Ma}$ \\
\hline $\begin{array}{l}\text { Tectonic } \\
\text { setting }\end{array}$ & & $\begin{array}{l}\text { Back-arc rift, post-subduction } \\
\text { extension }\end{array}$ & $\begin{array}{l}\text { Subduction-related continental } \\
\text { arc }\end{array}$ & $\begin{array}{l}\text { Syn- to post-collision tectonic } \\
\text { regime }\end{array}$ & $\begin{array}{l}\text { Subduction-related } \\
\text { continental arc }\end{array}$ \\
\hline Example & & $\begin{array}{l}\text { Climax (Wallace, 1995); } \\
\text { Colorado and Questa (Cline } \\
\text { and Bodnar, 1994; Klemm et } \\
\text { al., 2008); Urad-Henderson } \\
\text { (Seedorff and Einaudi, 2004a, } \\
\text { b) }\end{array}$ & $\begin{array}{l}\text { Endako (Selby et al., 2000); } \\
\text { MAX (Lawley et al., 2010); } \\
\text { Zhaiwa (Deng et al., 2013); } \\
\text { Luoboling (Zhong et al., 2014); } \\
\text { Diyanqin'amu (Wang et al., } \\
\text { 2016a) }\end{array}$ & $\begin{array}{l}\text { Yuchiling (Li et al., 2012a, 2013); } \\
\text { Qian'echong (Yang et al., 2013; } \\
\text { Mi et al., 2015); Donggebi (Wu et } \\
\text { al., 2014); Yaochong (Wang et al., } \\
\text { 2014); Donggou (Yang et al., } \\
\text { 2015a) }\end{array}$ & \\
\hline
\end{tabular}



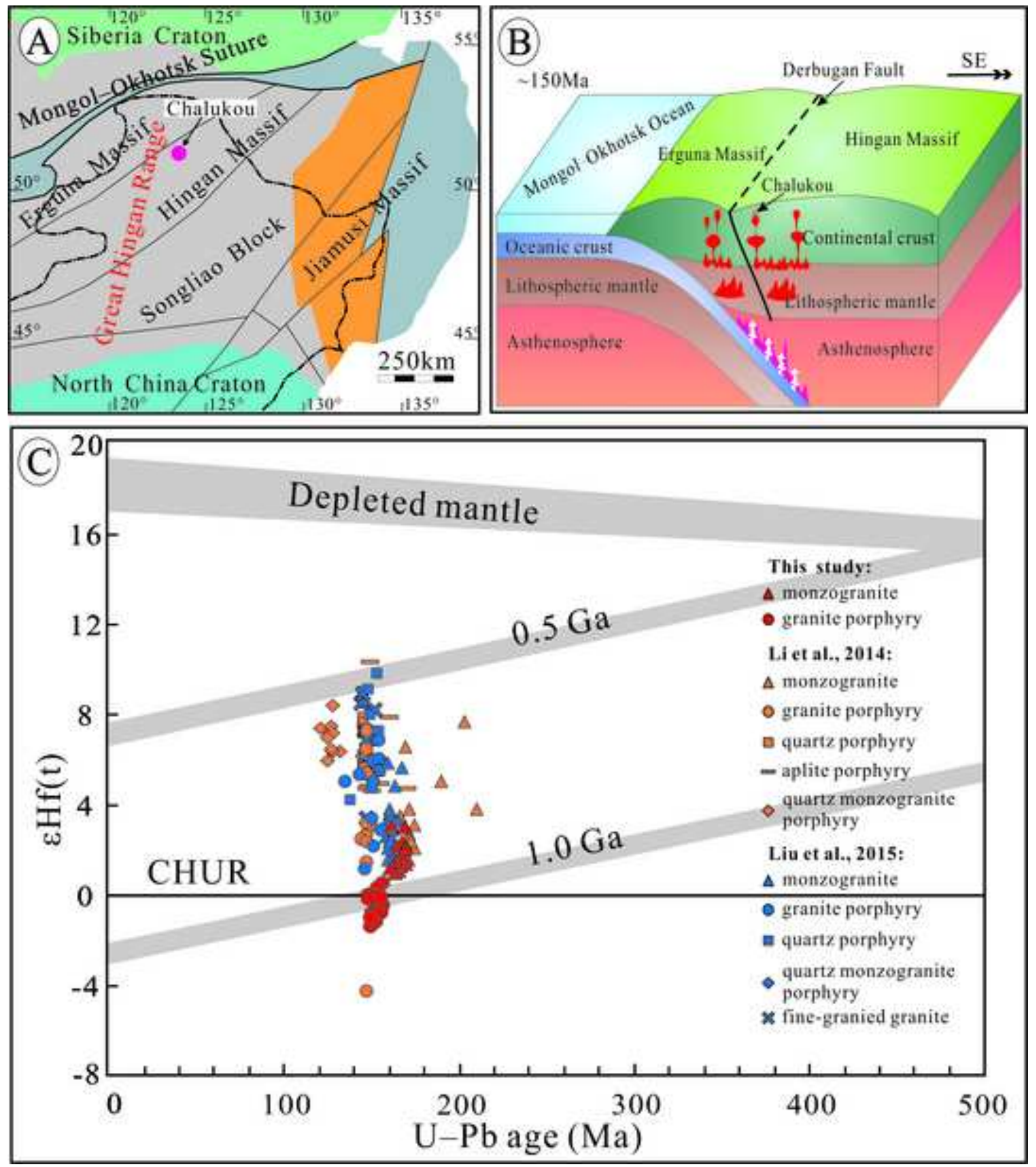